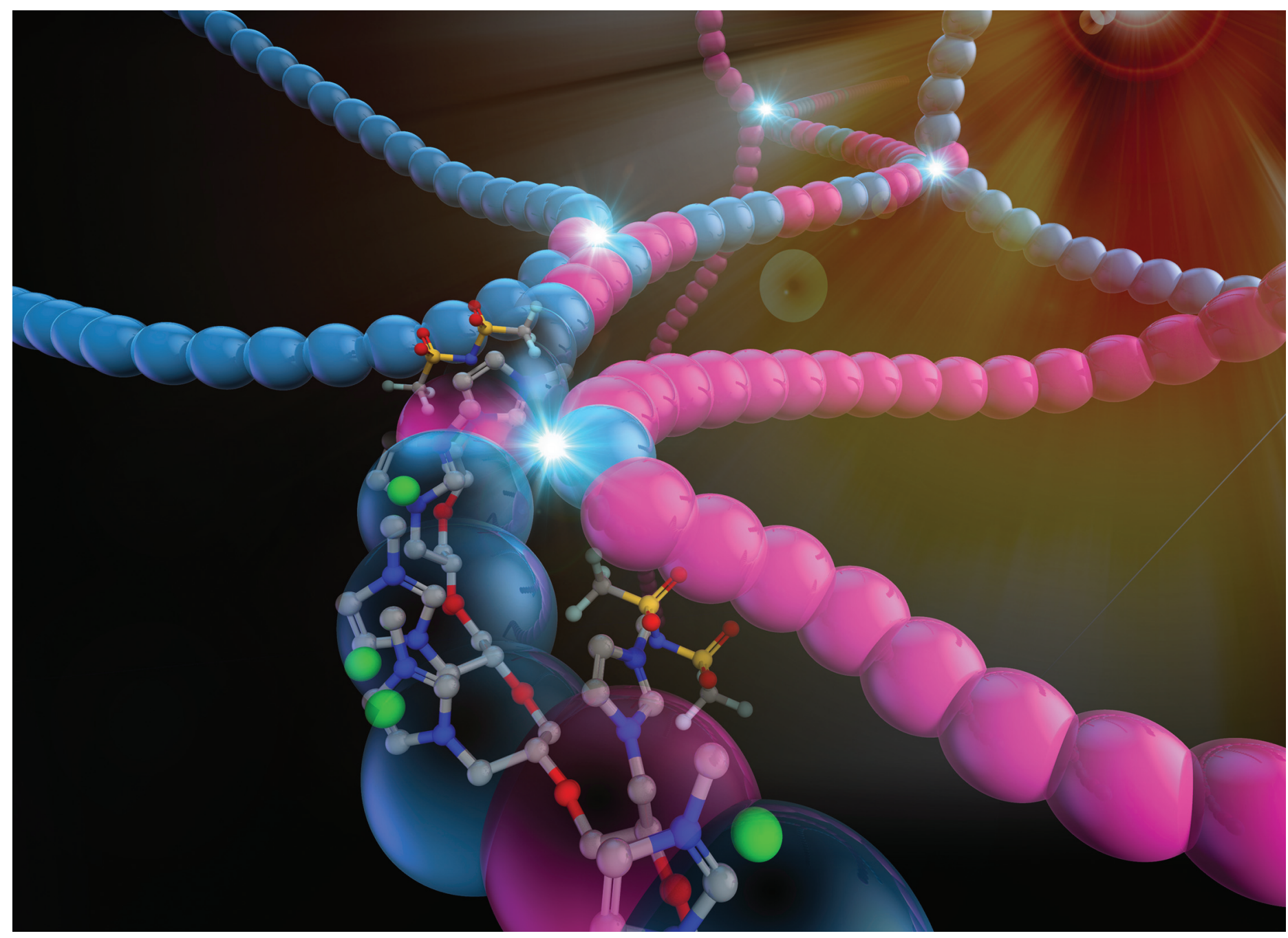

Highlighting research from Research \& Development Center, Zeon Corporation, Japan.

Syntheses, characterizations and functions of cationic polyethers with imidazolium-based ionic liquid moieties

Cationic polyethers with ionic liquid groups are characterized with deliquescence, ionic conductivity and miscibility in ionic materials. Since the cationic polyethers are miscible with each other to exchange anions, random copolymers can be prepared through simple mixing.
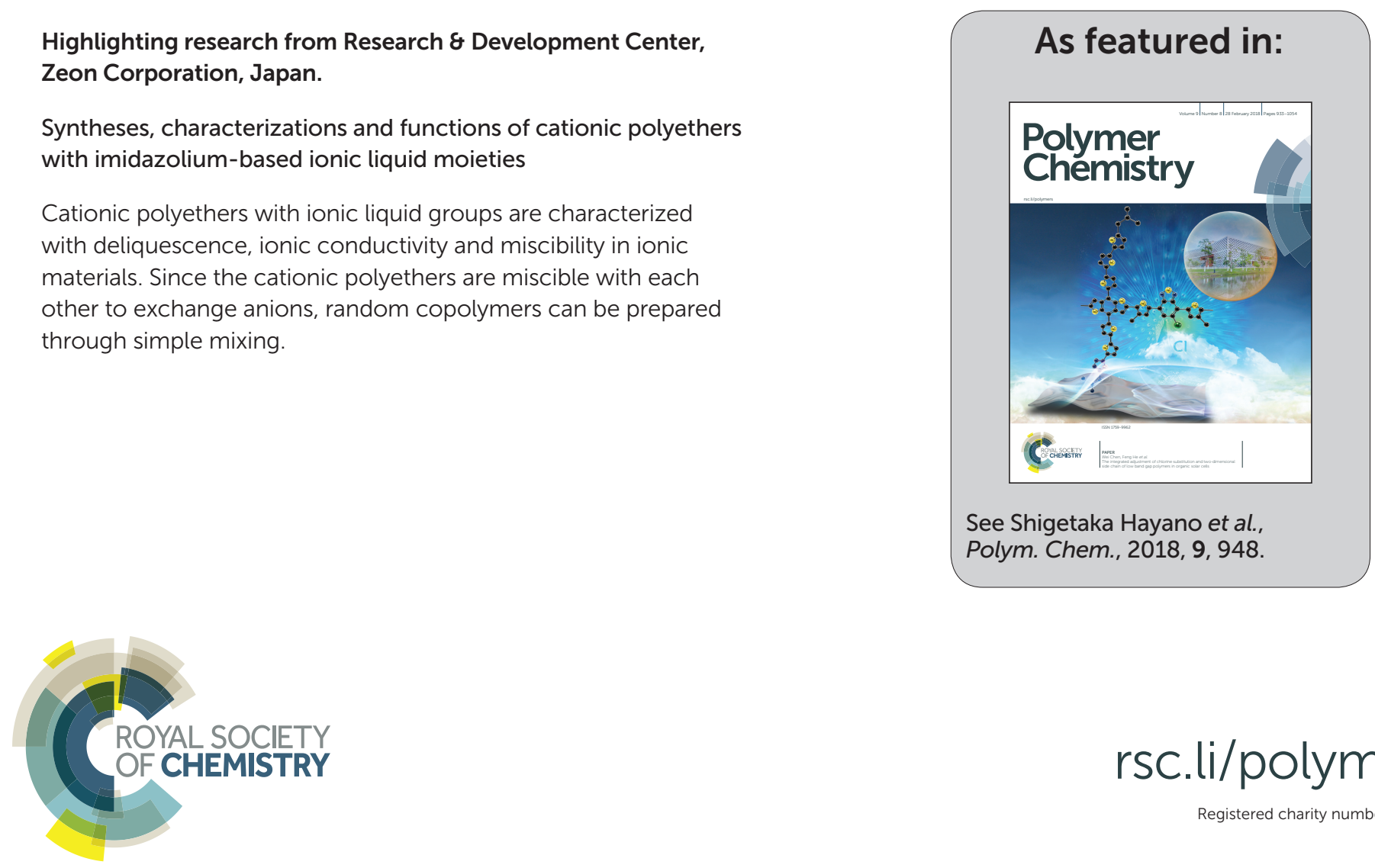


\section{A Check for updates}

Cite this: Polym. Chem., 2018, 9, 948

\title{
Syntheses, characterizations and functions of cationic polyethers with imidazolium-based ionic liquid moieties $\uparrow$
}

\author{
Shigetaka Hayano, (D) * Keisuke Ota and Hoang The Ban:
}

\begin{abstract}
Cationic polyethers with imidazolium-based ionic liquid moieties were synthesized and characterized thoroughly for their properties and functions. Poly(epichlorohydrin) (poly(ECH)) was quaternized by 1-methylimidazole to provide poly( $N$-glycidyl- $N^{\prime}$-methylimidazolium chloride) (poly $\left(\mathrm{ECH}-\mathrm{Melm}^{+} \mathrm{Cl}^{-}\right)$). Anion exchange of the poly $\left(\mathrm{ECH}-\mathrm{Melm}^{+} \mathrm{Cl}^{-}\right)$with $\mathrm{Li}$ salts provided other cationic polyethers: hydrophobic poly( $N$-glycidyl- $N^{\prime}$-methylimidazolium bis(trifluoromethanesulfonyl)imide) (poly(ECH-Melm $\left.{ }^{+} T F S I^{-}\right)$) and hydrophilic poly $\left(\mathrm{N}\right.$-glycidyl- $N^{\prime}$-methylimidazolium tetrafluoroborate) (poly $\left(\mathrm{ECH}^{-} \mathrm{Melm}{ }^{+} \mathrm{BF}_{4}^{-}\right)$). The $5 \%$ thermal decomposition temperatures of these cationic polyethers are quite high $\left(300-400{ }^{\circ} \mathrm{C}\right)$. Contrary to poly $(\mathrm{ECH})$ (glass transition temperature $\left(T_{\mathrm{g}}\right)=-49^{\circ} \mathrm{C}$ ), the poly $\left(\mathrm{ECH}-\mathrm{Melm}^{+} \mathrm{Cl}^{-}\right.$) is a polymer plastic $\left(T_{\mathrm{g}}=92{ }^{\circ} \mathrm{C}\right)$ when completely dry. Poly $\left(\mathrm{ECH}-\mathrm{Melm}^{+} \mathrm{TFSI}{ }^{-}\right)$is elastomeric $\left(T_{\mathrm{g}}=-12^{\circ} \mathrm{C}\right)$, whereas poly $\left(\mathrm{ECH}-\mathrm{Melm}^{+} \mathrm{BF}_{4}{ }^{-}\right)$is a plastic $\left(\mathrm{Tg}_{\mathrm{g}}=67^{\circ} \mathrm{C}\right)$. Poly $\left(\mathrm{ECH}-\mathrm{Melm}^{+} \mathrm{Cl}^{-}\right)$rapidly absorbed a large amount of moisture from the atmosphere, changing its appearance from solid to a viscous fluid even under relatively dry conditions $\left(23{ }^{\circ} \mathrm{C}\right.$, and $40 \%$ relative humidity $(\mathrm{RH})$; water uptake $\left.=29 \mathrm{wt} \%\right)$, suggesting its highly deliquescent nature. The hydrated poly $\left(\mathrm{ECH}-\mathrm{Melm}^{+} \mathrm{Cl}^{-}\right)$possesses neither a glass transition nor a phase transition between $-60^{\circ} \mathrm{C}$ and $80^{\circ} \mathrm{C}$. The ionic conductivity of the hydrated polymer is as high as $1.8 \times 10^{-2} \mathrm{~S} \mathrm{~cm}^{-1}$ under humid conditions $\left(23^{\circ} \mathrm{C}\right.$, and $80 \% \mathrm{RH}$; water uptake $\left.=72 \mathrm{wt} \%\right)$ and is dependent mainly on water uptake. The miscibility between the cationic polyethers and ionic liquids is quite high; mixtures of ethylmethylimidazolium bis(trifluoromethanesulfonyl)imide and the cationic polyethers had no phase transitions between $-70{ }^{\circ} \mathrm{C}$ and $100{ }^{\circ} \mathrm{C}$. Since the cationic polyethers were miscible with each other to exchange anions, random copolymers with desired copolymerization ratios can be prepared through simple mixing.
\end{abstract}

Received 24th November 2017 Accepted 24th January 2018

DOI: 10.1039/c7py01985h

rsc.li/polymers

\section{Introduction}

An ionic liquid is generally defined as a molten organic salt with a melting point lower than $100{ }^{\circ} \mathrm{C} .{ }^{1}$ Since their discovery, ionic liquids have been extensively studied due to their high ionic densities, fluidities and negligible vapor pressures. ${ }^{2-4}$ Recent reports show that the properties of ionic liquids largely depend on the combination of the cation and anion that are chosen from the ionic liquid library.

An ionic polymer is comprised of a polymer chain and a positively or negatively charged ionic moiety in each repeating

Zeon Corporation R\&D Center, 1-2-1 Yako, Kawasaki-ward, Kawasaki-city,

Kanagawa-pref., 210-9507, Japan.E-mail: S.Hayano@zeon.co.jp

$\dagger$ Electronic supplementary information (ESI) available: Details of the living polymerization of ECH, schemes, figures and tables. See DOI: 10.1039/ c7py01985h

\$Present address: Saigon Hi-Tech Park Incubation Center, K1-G3, D1 Road, Dist. 9, HCMC, Vietnam. unit. A poly(ionic liquid) (poly(IL)) is recognized as a specific type of ionic polymer in which the ionic group is composed of an organic cation and anion..$^{5-7}$ The synthesis and properties of poly(IL)s have been extensively studied in the past two decades, and now it is established as an emerging field in chemistry. ${ }^{8-21}$ The development of poly(IL)s not only allowed combining the unique properties of ionic liquids with the processability and solidity of polymer materials, but also allowed for the attainment of new functions. There are two basic methods to synthesize poly(IL)s. One is the direct polymerization of ionic liquid monomers, and the other is the quaternization of existing polymer materials. Most poly(IL)s are vinyl polymers, having quaternary ammonium salts as side groups. Since propagation radicals are stable in the presence of ionic moieties and polar impurities, the poly(IL)s are synthesized using free radical polymerization or the controlled radical polymerization of vinyl monomers with ionic liquid groups. Consequently, conventional poly(IL)s mostly have hydrocarbon main chains which work as hydrophobic and rigid com- 
ponents for the ionic polymer materials. However, methodologies to synthesize a poly(IL) with a polar main chain have still been quite limited. One can expect that the polar backbone would enhance the polarity of the polymer, and increase the ionic conductivity and the hydrophilicity.

Polyethers are versatile polar elastic materials with hydrophilic and flexible chains. For instance, non-substituted poly (ethylene oxide) is a hydrophilic crystalline elastomer, while substituted ones such as poly(propylene oxide) and poly(epichlorohydrin) (poly(ECH)) are hydrophobic elastomers due to their non-polar side groups. Poly(ethylene oxide) is commonly used in a variety of applications due to its hydrophilicity, high solubility of ionic materials, ionic conductivity and low toxicity, originating from the poly(oxirane) backbone. Poly (ethylene oxide) is generally synthesized via the living anionic polymerization of ethylene oxide using alkaline metal-based initiators. ${ }^{22}$ Substituted polyethers such as poly(ECH) and its copolymers are mainly applied as synthetic rubbers. These polyethers are prepared using coordination anionic polymerization catalysts. ${ }^{23-25}$ Due to the limited ability of coordination anionic polymerization catalysts to precisely control the polymerization, the existing poly(ECH) and ECH-copolymers have extremely high molecular weights (MW) and broad molecular weight distributions (MWD). Recently, many researchers have developed new Al-based catalysts for living polymerizations of ethylene oxide and propylene oxide with high initiation efficiencies. ${ }^{26-28}$ Deffieux's group ${ }^{29,30}$ and our group $^{31}$ have independently developed the living anionic polymerization of functional epoxides such as epichlorohydrin (ECH). This method appeared to be a useful tool to accomplish the control of the molecular weight, molecular weight distribution and end functionality of polyethers. Poly(ECH), with a controlled structure, could be a useful precursor for a new type of well-defined poly(IL) if the chloromethyl group of each repeating unit can be quaternized by a tertiary amine such as 1-methylimidazole in a quantitative manner.

The cationization of high MW poly(ECH) and ECH-copolymers has not been thoroughly investigated. Stoica's group studied the quaternization of a commercially available ECHcopolymer using a mixture of 1-azabicyclo-[2.2.2]-octane and 1,4-diazabicyclo-[2.2.2]-octane. Unfortunately, the cationization ratio appeared to be around $10 \%$ and the obtained polymer was not fully characterized. ${ }^{32,33}$ In our unpublished data, the quaternization of commercially available poly(ECH) was quite difficult because of its high MW. ${ }^{34}$ Recently, the quaternization of poly(ECH) with a well-controlled MW was studied by Baker et al. ${ }^{35,36}$ and by our group. ${ }^{37,38}$ Baker's group focused on the synthesis and properties of cationic polyether with less polar butylimidazolium bis(trifluoromethanesulfonyl)imide in each repeating unit, however, the molecular structure has not been fully characterized. To our knowledge there is no report concerning cationized poly(ECH) with highly polar methylimidazolium chloride. Furthermore, it can be expected that imidazolium-based poly(IL)s with ether groups would be unique materials due to competitive interactions between the ether oxygens and anions with the imidazolium protons. ${ }^{39}$ In particular, such competitive interactions would weaken the cation-anion interactions of the ionic groups and change various functions of the poly(IL), including the thermal properties, ionic conductivity and affinity to $\mathrm{CO}_{2} \cdot{ }^{20,36}$

Here we report on well-defined cationic polyethers with imidazolium-based ionic liquid moieties in each repeating unit, with narrow MWDs. Living anionic polymerization of epichlorohydrin was conducted first, and then quaternization of the obtained poly(ECH) was carried out. As a result, well-defined poly(ECH) was successfully quaternized using 1-methylimidazole to produce a highly hydrophilic cationic polyether, poly $\left(N\right.$-glycidyl- $N^{\prime}$-methylimidazolium chloride) (poly $(\mathrm{ECH}-$ MeIm $\left.{ }^{+} \mathrm{Cl}^{-}\right)$), with desirable outcomes. It is worthy to note that poly $\left(\mathrm{ECH}-\mathrm{MeIm}^{+} \mathrm{Cl}^{-}\right)$is a highly deliquescent polymer. The hydrated poly(ECH-MeIm $\left.{ }^{+} \mathrm{Cl}^{-}\right)$was characterized with high ionic conductivity and high water retention. Furthermore, anion exchanges of the poly $\left(\mathrm{ECH}-\mathrm{MeIm}^{+} \mathrm{Cl}^{-}\right)$were conducted using lithium salts to form poly $(N$-glycidyl- $N$ '-methylimidazolium bis(trifluoromethanesulfonyl)imide) (poly(ECH$\left.\left.\mathrm{MeIm}^{+} \mathrm{TFSI}^{-}\right)\right)$and poly$\left(N\right.$-glycidyl- $N^{\prime}$-methylimidazolium tetrafluoroborate) (poly(ECH-MeIm $\left.{ }^{+} \mathrm{BF}_{4}^{-}\right)$). The variety of the properties of these cationized polyethers depended mainly on the combination of cation and anion. These cationized polyethers showed high miscibility with imidazolium-based ionic liquids. The cationic polyethers were miscible with each other to exchange anions, therefore a random copolymer with a desired copolymerization ratio was prepared using simple mixing.

\section{Experimental}

\section{General remarks}

All operations were carried out in a glove-box (nitrogen atmosphere, $\mathrm{O}_{2}<1 \mathrm{ppm}$ and $\mathrm{H}_{2} \mathrm{O}<1 \mathrm{ppm}$ ) or under an argon atmosphere using standard Schlenk techniques. $\mathrm{Me}_{3} \mathrm{Al}$ (Kanto Chemical), $\mathrm{Et}_{3} \mathrm{Al}$ (Kanto Chemical), i-Bu $\mathrm{Bu}_{3} \mathrm{Al}$ (Kanto Chemical), $n-\mathrm{Oc}_{3} \mathrm{Al}$ (Kanto Chemical), $\mathrm{Me}_{4} \mathrm{NBr}$ (Tokyo Kasei), $n-\mathrm{Bu}_{4} \mathrm{NBr}$ (Tokyo Kasei), $n$ - $\mathrm{Oc}_{4} \mathrm{NBr}$ (Tokyo Kasei), lithium bis(trifluoromethanesulfonyl)imide (LiTFSI) (Kanto Chemical), lithium tetrafluoroborate $\left(\mathrm{LiBF}_{4}\right)$ (Kanto Chemical), ethylmethylimidazolium bis(trifluoromethanesulfonyl)imide $\left(\left[\mathrm{EMIm}^{+}\right]\right.$ [TFSI $\left.{ }^{-}\right]$) (Tokyo Kasei), butylmethylimidazolium bis(trifluoromethanesulfonyl)imide ([BMIm $\left.{ }^{+}\right]\left[\mathrm{TFSI}^{-}\right]$) (Tokyo Kasei), ethylmethylimidazolium chloride $\left(\left[\mathrm{EMIm}^{+}\right]\left[\mathrm{Cl}^{-}\right]\right)$(Tokyo Kasei), butylmethylimidazolium chloride $\left(\left[\mathrm{BMIm}^{+}\right]\left[\mathrm{Cl}^{-}\right]\right)$(Tokyo Kasei), ethylmethylimidazolium tetrafluoroborate $\left(\left[\mathrm{EMIm}^{+}\right]\right.$ $\left[\mathrm{BF}_{4}^{-}\right]$) (Aldrich) and butylmethylimidazolium tetrafluoroborate $\left(\left[\mathrm{BMIm}^{+}\right]\left[\mathrm{BF}_{4}^{-}\right]\right.$) (Aldrich) were used as received. Dehydrated reaction solvents such as toluene, tetrahydrofuran (THF), acetonitrile $\left(\mathrm{CH}_{3} \mathrm{CN}\right)$, dimethylsulfoxide (DMSO) and 1,4-dioxane were used without further purification. Epichlorohydrin (Tokyo Kasei) and 1-methylimidazole (Wako Chemicals) were distilled from calcium hydride. Chloroform- $d$ $\left(\mathrm{CDCl}_{3}\right)$ and dimethylsulfoxide- $d_{6}$ (DMSO- $\left.d_{6}\right)$ were dehydrated using activated molecular sieves $3 \mathrm{~A}$ prior to use. $n$-Hexane, 
chloroform $\left(\mathrm{CHCl}_{3}\right)$, dimethylformamide (DMF), acetone and methanol $(\mathrm{MeOH})$ were used as received. Water was purified using a deionizer.

\section{Analysis of the polymers}

${ }^{1} \mathrm{H}$ and ${ }^{13} \mathrm{C}$ NMR spectra were obtained using a JEOL JNM-EX400WB spectrometer $\left(399.78 \mathrm{MHz}\right.$ for ${ }^{1} \mathrm{H}$ and $100.53 \mathrm{MHz}$ for ${ }^{13} \mathrm{C}$ ) at $25{ }^{\circ} \mathrm{C}$ or on a Bruker Avance III $500 \mathrm{MHz}$ spectrometer $\left(500.13 \mathrm{MHz}\right.$ for ${ }^{1} \mathrm{H}$ and $125.77 \mathrm{MHz}$ for ${ }^{13} \mathrm{C}$ ) at $27^{\circ} \mathrm{C}$. Chemical shifts were determined using tetramethylsilane $(\delta 0.00 \mathrm{ppm})$, dimethylsulfoxide $(\delta 2.50 \mathrm{ppm}$ for ${ }^{1} \mathrm{H}, \delta 39.5 \mathrm{ppm}$ for ${ }^{13} \mathrm{C}$ ) or chloroform $\left(\delta 7.24 \mathrm{ppm}\right.$ for ${ }^{1} \mathrm{H}$, $\delta 77.2$ ppm for ${ }^{13} \mathrm{C}$ ) as references. The molecular weights (MW) of the polymers were estimated using a gel-permeation chromatograph (GPC) (Tosoh HLC-8220 GPC; eluent THF, or Tosoh HLC-8320 GPC; eluent $0.1 \mathrm{M} \mathrm{NaNO}_{3} \mathrm{aq}$ ). The relative numberand weight-average molecular weights $\left(M_{\mathrm{n}}\right.$ and $M_{\mathrm{w}}$, respectively) and molecular weight distribution (MWD; $M_{\mathrm{w}} / M_{\mathrm{n}}$ ) were acquired from calibration curves obtained using polystyrene or poly(ethylene oxide) standards. Differential scanning calorimetry (DSC) measurements were performed on a SII NanoTechnology X-DSC7000 under a dry nitrogen stream. Thermogravimetry (TG/DTA) was recorded on a SII NanoTechnology TG/DTA7200 under a dry nitrogen stream. Water uptake was measured using gravimetry in a thermohygrostat chamber (Espec Corp., TBL-2HW2P3A). Ionic conductivity values were estimated using electrochemical impedance spectroscopy, using a Solartron 1281 Multiplexer (Toyo Technica) and a Solartron 1287 Electrochemical Interphase (Toyo Technica) in the frequency range of $32 \mathrm{MHz}$ to $0.1 \mathrm{~Hz}$ at $25{ }^{\circ} \mathrm{C}$. The samples for the impedance spectroscopy were placed between aluminum electrodes in a thermo-hygrostat chamber, and then sealed prior to the measurement.

\section{Syntheses of the polymers}

Preparation of the initiator system. Unless otherwise stated, a solution of the initiator system was prepared as follows: a $5 \mathrm{~mL}$ toluene dispersion of $n-\mathrm{Bu}_{4} \mathrm{NBr}(0.322 \mathrm{~g}, 1.0 \mathrm{mmol})$ was mixed with 1.2 equivalents of $\mathrm{Et}_{3} \mathrm{Al}$ in an $n$-hexane solution at room temperature. The mixture was stirred at room temperature for 15 min resulting in a colorless homogeneous solution.

Polymerization of ECH. Polymerization of ECH was conducted using the following procedure, which is described in detail in the literature ${ }^{38}$ and in the ESI. $\uparrow$ The polymerization was carried out in a pre-baked ampoule tube equipped with a rubber septum at $0{ }^{\circ} \mathrm{C}$. A $30 \mathrm{~mL}$ toluene solution of $\mathrm{ECH}(10 \mathrm{~g}$, $108 \mathrm{mmol}$ ) was added to the initiator mixture mentioned above at the prescribed temperature. After stirring the reaction mixture for $5 \mathrm{~h}$, the polymerization was quenched with a large amount of methanol $/ \mathrm{H}_{2} \mathrm{O}$. The quenched mixture was washed with $\mathrm{HCl}$ aq. to remove any catalyst residue followed by distilled water for neutralization, and finally dried in vacuo at $40{ }^{\circ} \mathrm{C}$ for $24 \mathrm{~h}$ to form poly $(\mathrm{ECH})\left(M_{\mathrm{n}}=10000, M_{\mathrm{w}} / M_{\mathrm{n}}=1.13\right.$, and DP $=108$; Table S1, run $7 \dagger)$. The polymer yield was determined using gravimetric measurement.
Quaternization of poly(ECH). A $50 \mathrm{wt} \% \mathrm{CH}_{3} \mathrm{CN}$ solution of $\operatorname{poly}(\mathrm{ECH})\left(M_{\mathrm{n}}=10000, M_{\mathrm{w}} / M_{\mathrm{n}}=1.13\right.$, and DP = 108; Table S1, run $7 \dagger$ ) and 1-methylimidazole, equimolar to the ECH units, were introduced in a glass flask equipped with a three-way stopcock. The mixture containing $26 \mathrm{wt} \%$ of the poly $(\mathrm{ECH})$ was then heated to the reaction temperature. The quaternization reaction of the poly $(\mathrm{ECH})$ was carried out at $80^{\circ} \mathrm{C}$ for $96 \mathrm{~h}$ with stirring. At the end of the polymer reaction, a fully cationized polyether reprecipitated as an oil. After the quaternization, the reaction mixture was cooled to room temperature. The resulting poly $(N$-glycidyl- $N$ '-methylimidazolium chloride), $\operatorname{poly}\left(\mathrm{ECH}-\mathrm{MeIm}^{+} \mathrm{Cl}^{-}\right)\left(M_{\mathrm{n}(\text { calc })}=18900\right.$, and $\left.\mathrm{DP}=108\right)$, was washed with acetone to remove residual acetonitrile and 1-methylimidazole, and dried in vacuo at $80^{\circ} \mathrm{C}$ for $24 \mathrm{~h}$. ${ }^{1} \mathrm{H}$ NMR and ${ }^{13} \mathrm{C}$ NMR spectra of the obtained poly $\left(\mathrm{ECH}-\mathrm{MeIm}^{+} \mathrm{Cl}^{-}\right)$are illustrated in Fig. S1(a) and (b), $\dagger$ respectively. A theoretically predicted number-average molecular weight of the poly $\left(\mathrm{ECH}-\mathrm{MeIm}^{+} \mathrm{Cl}^{-}\right)$was obtained using the following equation: $M_{\mathrm{n} \text { (calc) }}=$ (MW of $N$-glycidyl- $N$ '-methylimidazolium chloride $) \times(\mathrm{DP}$ of the poly $(\mathrm{ECH})$ as a starting material).

Synthesis of poly( $N$-glycidyl- $N$ '-methylimidazolium bis(trifluoromethanesulfonyl)imide) (poly(ECH-MeIm ${ }^{+}$TFSI $\left.^{-}\right)$) via the anion exchange of poly $\left(\mathrm{ECH}-\mathrm{MeIm}^{+} \mathrm{Cl}^{-}\right)$and lithium bis (trifluoromethanesulfonyl)imide (LiTFSI). Aqueous solutions of LiTFSI (10 wt\%) and poly(ECH-MeIm $\left.{ }^{+} \mathrm{Cl}^{-}\right)\left(M_{\mathrm{n} \text { (calc) }}=18900\right.$, and $\mathrm{DP}=108)(10 \mathrm{wt} \%)$ were mixed at room temperature and stirred for $30 \mathrm{~min}$. The mole ratio of LiTFSI and $\mathrm{MeIm}^{+} \mathrm{Cl}^{-}$ groups was equivalent. The resulting polymer precipitated as a viscous oil just after mixing. After separating the viscous oil compound from the aqueous LiCl solution by decantation, the polymer was dried in vacuo at $80{ }^{\circ} \mathrm{C}$ for $24 \mathrm{~h}$ to produce poly $(N$-glycidyl- $N$ '-methylimidazolium bis(trifluoromethanesulfonyl)imide) (poly(ECH-MeIm ${ }^{+}$TFSI $\left.\left.^{-}\right)\right)\left(M_{\mathrm{n}(\text { calc })}=45400\right.$, and $\mathrm{DP}=108)$ as a viscous, transparent oil. ${ }^{1} \mathrm{H} \mathrm{NMR}$ and ${ }^{13} \mathrm{C} \mathrm{NMR}$ spectra of the obtained poly $\left(\mathrm{ECH}-\mathrm{MeIm}^{+} \mathrm{TFSI}^{-}\right)$are described in Fig. S2(a) and (b), $\dagger$ respectively. A theoretically predicted number-average molecular weight of the poly (ECH-MeIm ${ }^{+} \mathrm{TFSI}^{-}$) was obtained using the following equation: $M_{\text {n(calc) }}=$ (MW of $N$-glycidyl- $N$ '-methylimidazolium bis(trifluoromethanesulfonyl)imide $) \times(\mathrm{DP}$ of the poly $(\mathrm{ECH})$ as a starting material).

Synthesis of poly( $N$-glycidyl- $N^{\prime}$-methylimidazolium tetrafluoroborate) (poly $\left(\mathrm{ECH}-\mathrm{MeIm}^{+} \mathrm{BF}_{4}{ }^{-}\right)$) via the anion exchange of poly $\left(\mathrm{ECH}-\mathrm{MeIm}^{+} \mathrm{Cl}^{-}\right)$and lithium tetrafluoroborate $\left(\mathrm{LiBF}_{4}\right)$. Methanol solutions of $\mathrm{LiBF}_{4} \quad(10 \quad \mathrm{wt} \%)$ and poly $\left(\mathrm{ECH}-\mathrm{MeIm}^{+} \mathrm{Cl}^{-}\right)\left(M_{\mathrm{n}(\mathrm{calc})}=18900\right.$, and $\left.\mathrm{DP}=108\right)(10 \mathrm{wt} \%)$ were mixed at room temperature and stirred for $30 \mathrm{~min}$. The mole ratio of $\mathrm{LiBF}_{4}$ and $\mathrm{MeIm}^{+} \mathrm{Cl}^{-}$groups was equivalent. The resulting polymer precipitated as a viscous oil just after mixing. After separating the viscous oil compound from the methanol LiCl solution by decantation, the polymer was dried in vacuo at $80{ }^{\circ} \mathrm{C}$ for $24 \mathrm{~h}$ to produce poly $(N$-glycidyl- $N$-methylimidazolium tetrafluoroborate) (poly(ECH-MeIm $\left.{ }^{+} \mathrm{BF}_{4}{ }^{-}\right)$) $\left(M_{\mathrm{n} \text { (calc) }}=24500\right.$, and DP $\left.=108\right)$ as a brittle, transparent resin. ${ }^{1} \mathrm{H}$ NMR and ${ }^{13} \mathrm{C}$ NMR spectra of the obtained poly 
(ECH-MeIm ${ }^{+} \mathrm{BF}_{4}{ }^{-}$) are described in Fig. S3(a) and (b), $\dagger$ respectively. A theoretically predicted number-average molecular weight of the poly $\left(\mathrm{ECH}-\mathrm{MeIm}^{+} \mathrm{BF}_{4}{ }^{-}\right)$was calculated based on the following equation: $M_{\mathrm{n} \text { (calc) }}=$ (MW of $N$-glycidyl $-N^{\prime}$-methylimidazolium tetrafluoroborate $) \times(\mathrm{DP}$ of the poly $(\mathrm{ECH})$ as a starting material).

\section{Results and discussion}

\section{Synthesis of cationic polyether: quaternization of poly $(\mathrm{ECH})$} and successive anion exchange

Cationic polyethers with imidazolium-based ionic liquid moieties were synthesized using the living anionic polymerization of epichlorohydrin (ECH), followed by quaternization of the chloromethyl groups of poly(epichlorohydrin) (poly(ECH)) with 1-methylimidazole, and anion exchange of the formed imidazolium chloride groups (Scheme 1). In this section, the quaternization and anion exchange processes are outlined in detail, while the living polymerization of $\mathrm{ECH}$ is described in the ESI. $\dagger$

It is well known that the quaternization reaction between a tertiary amine and an alkyl halide can be accelerated in polar solvents such as $\mathrm{CH}_{3} \mathrm{CN}$ and DMF. Thus, it appears relevant that the polarity of a solvent would influence the quaternization of the chloromethyl groups in poly(ECH). Therefore, we investigated the effect of reaction solvent on the quaternization of poly $(\mathrm{ECH})\left(M_{\mathrm{n}}=1200\right.$, and $M_{\mathrm{w}} / M_{\mathrm{n}}=1.22$; Table $\mathrm{S} 1$, run $\left.5 \dagger\right)$ using 1-methylimidazole first, with the results summarized in Fig. S8. $\uparrow$ When toluene was used as the solvent, all of the polymers precipitated during the early period of quaternization, and as a result, the cationization reaction levelled off at a low quaternization ratio. The quaternization proceeded slowly to a certain extent in THF, however the reaction mixture became heterogeneous during the middle period of the reaction. In contrast, polar solvents were shown to be suitable for full quaternization of poly(ECH). The polymer reaction proceeded smoothly and steadily in $\mathrm{CH}_{3} \mathrm{CN}$, and eventually a fully cationized polymer precipitated as an oil at the end of the polymer reaction. DMSO and 1,4-dioxane were also found to be good solvents for the quaternization of poly(ECH). Cationization proceeded relatively fast when poly(ECH) and 1-methylimidazole were mixed and heated in bulk. In this study, we decided to employ $\mathrm{CH}_{3} \mathrm{CN}$ as the reaction solvent for the quaternization of the polymer.

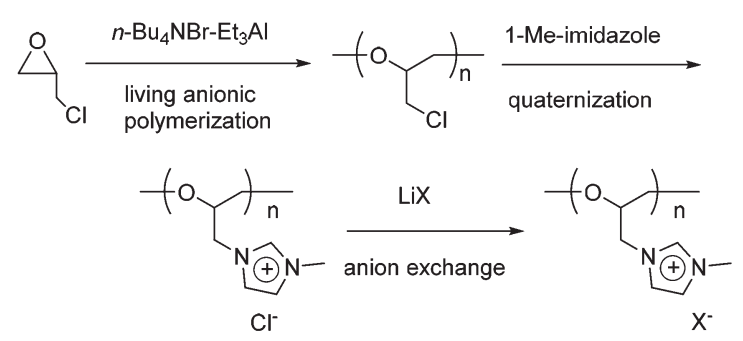

Scheme 1 Synthesis of cationic polyether.
To describe the cationization in detail, the poly(ECH) $\left(M_{\mathrm{n}}=\right.$ 1200 ; degree of polymerization $(\mathrm{DP})=13 ; M_{\mathrm{w}} / M_{\mathrm{n}}=1.22$ (Table $\mathrm{S} 1$, run $5 \dagger$ )) was quaternized in the presence of 2 equivalents of 1-methylimidazole for each chloromethyl group, in $\mathrm{CH}_{3} \mathrm{CN}$ at $80{ }^{\circ} \mathrm{C} .{ }^{40}$ The quaternization ended within $96 \mathrm{~h}$ resulting in fully cationized polyether, precipitated as an oil. The obtained oily compound was first washed with acetone in order to extract 1-methylimidazole and $\mathrm{CH}_{3} \mathrm{CN}$, and then dried in vacuo at $80^{\circ} \mathrm{C}$ for $24 \mathrm{~h}$ to remove residual volatiles and to isolate poly $(N$-glycidyl- $N$ '-methylimidazolium chloride) (poly $\left(\mathrm{ECH}-\mathrm{MeIm}^{+} \mathrm{Cl}^{-}\right)$) as a brittle polymer plastic (a macroscopic view is shown in Fig. 5(a)). Fig. 1 shows the ${ }^{1} \mathrm{H}$ NMR spectra and GPC traces of the poly $(\mathrm{ECH})$ before and after quaternization. In Fig. 1(b), proton signals of the poly $\left(\mathrm{ECH}-\mathrm{MeIm}^{+} \mathrm{Cl}^{-}\right)$ are observed between $8-10 \mathrm{ppm}$. The chemical shifts of the imidazolium protons are similar to those of $\left[\mathrm{EMIm}^{+}\right]\left[\mathrm{Cl}^{-}\right]$and appear in a lower magnetic field compared to those of 1-methylimidazole (Fig. S9† illustrates selected ${ }^{1} \mathrm{H}$ NMR spectra of $\left[\mathrm{EMIm}^{+}\right]\left[\mathrm{Cl}^{-}\right]$and poly $\left.\left(\mathrm{ECH}-\mathrm{MeIm}^{+} \mathrm{Cl}^{-}\right)\right)$. The integration ratios between the protons in the imidazolium ring and the protons in the main chain suggest the full conversion of the chloromethyl groups to form the imidazolium chloride groups. It is interesting that there are no proton signals attributable to compounds derived from side reactions, including the Hofmann elimination. The proton signal at $6 \mathrm{ppm}$ is attributed to the terminal $\mathrm{OH}$ group. Fig. 1 also illustrates GPC traces of the poly(ECH) before (c) and after (d) the quaternization. THF was chosen as the eluent for poly(ECH), while $0.1 \mathrm{M}$ $\mathrm{NaNO}_{3}$ aq. was chosen for poly $\left(\mathrm{ECH}-\mathrm{MeIm}^{+} \mathrm{Cl}^{-}\right)$. Suitable GPC columns were employed for each condition. It is noteworthy that the obtained cationic polyether kept a narrow MWD during the polymer reaction at $80^{\circ} \mathrm{C}$ for $96 \mathrm{~h}$, suggesting no degradation of the main chain. In contrast, when poly(ECH) was quaternized at $150{ }^{\circ} \mathrm{C}$, the GPC elution curve of the

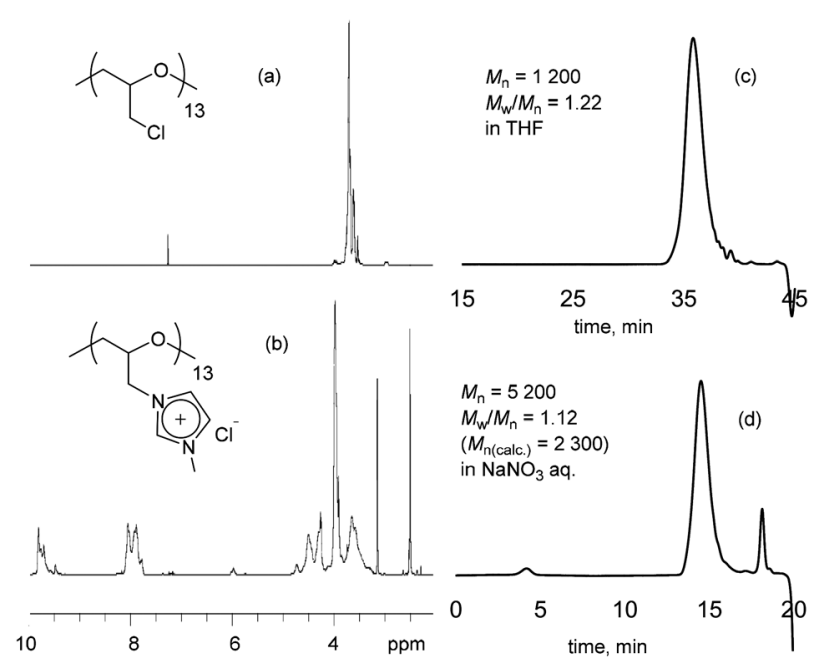

Fig. $1{ }^{1} \mathrm{H}$ NMR spectra of (a) poly(ECH) (in $\mathrm{CDCl}_{3} ; M_{\mathrm{n}}=1200 ; \mathrm{DP}=13$, as described in Table $\mathrm{S} 1$, run $5 \dagger$ ) and (b) poly $\left(\mathrm{ECH}-\mathrm{Melm}^{+} \mathrm{Cl}^{-}\right.$) (in DMSO$d_{6} ; M_{\text {n(calc) }}=2300 ; \mathrm{DP}=13$ ), and GPC chromatograms of (c) poly $(\mathrm{ECH})$ and (d) poly(ECH-Melm $\left.{ }^{+} \mathrm{Cl}^{-}\right)$. 
cationized poly(ECH) became broad, suggesting degradation of the main chain. Therefore it can be concluded that poly $\left(\mathrm{ECH}-\mathrm{MeIm}^{+} \mathrm{Cl}^{-}\right)$is unstable at high temperatures when it is in a solution, and that the quaternization must not be performed at high temperature.

To summarize, the data in Fig. 1 indicate that cationic polyether, poly $\left(\mathrm{ECH}-\mathrm{MeIm}^{+} \mathrm{Cl}^{-}\right)$, was successfully produced. The estimated $M_{\mathrm{n}}$ of poly(ECH) from GPC (PSt calibration) is almost identical to the predicted $M_{\mathrm{n}}$ value based on the following equation: $M_{\mathrm{n} \text { (calc) }}=$ (ECH loading $\left./ \mathrm{g}\right) /\left(n-\mathrm{Bu}_{4} \mathrm{NBr}\right.$ loading $/$ $\mathrm{mol}$ ). On the other hand, the relative $M_{\mathrm{n}}$ of poly $\left(\mathrm{ECH}-\mathrm{MeIm}^{+} \mathrm{Cl}^{-}\right.$) collected using GPC is 5200, as acquired using poly(ethylene glycol) calibration, which differs from the predicted value $\left(M_{\mathrm{n}(\mathrm{calc})}=2300\right.$; DP $\left.=13\right)$. At this moment, the origin of the inaccurate MW reading of poly $\left(\mathrm{ECH}-\mathrm{MeIm}^{+} \mathrm{Cl}^{-}\right)$ from GPC is not evident. It is presumable that repulsion of the ionic moiety or partial anion exchange of the poly (ECH-MeIm ${ }^{+} \mathrm{Cl}^{-}$) with $\mathrm{NaNO}_{3}$ in the eluent, or a combination of both, might have influenced the hydrodynamic volume of the polymer. We performed additional GPC analyses of poly $\left(\mathrm{ECH}-\mathrm{MeIm}^{+} \mathrm{Cl}^{-}\right)$samples with different MWs ((a) $M_{\mathrm{n} \text { (calc) }}=$ $1900 ; \mathrm{DP}=11$, (b) $M_{\mathrm{n} \text { (calc) }}=5800 ; \mathrm{DP}=33$, and (c) $M_{\mathrm{n} \text { (calc) }}=$ $16200 ; \mathrm{DP}=92)$ produced from poly $(\mathrm{ECH})$ samples of different MW. GPC elution curves of the poly(ECH-MeIm $\left.{ }^{+} \mathrm{Cl}^{-}\right)$ samples are depicted in Fig. S10. $\dagger$ All of the polymers retained their narrow MWDs after the cationization reaction, irrespective of their MWs. A peak shift was observed for the retention time when the MW of the starting polymer changed. The results implied that the hydrodynamic volumes of the cationic polyethers are dependent on their molecular weights. In conclusion, cationic polyether, poly $\left(\mathrm{ECH}-\mathrm{MeIm}^{+} \mathrm{Cl}^{-}\right)$, was successfully produced.

Anion exchange of poly (ECH-MeIm $\left.{ }^{+} \mathrm{Cl}^{-}\right)$with LiTFSI was investigated. Aqueous solutions of LiTFSI and poly $\left(\right.$ ECH-MeIm $\left.{ }^{+} \mathrm{Cl}^{-}\right)\left(M_{\mathrm{n}(\text { calc })}=2300 ; \mathrm{DP}=13\right)$, depicted in Fig. 1(b) and (d), were mixed at room temperature and stirred for 30 min with an equal mole ratio between the LiTFSI and $\mathrm{MeIm}^{+} \mathrm{Cl}^{-}$groups. A viscous oily compound precipitated just after mixing these two aqueous solutions. After separation of the resulting compound from the $\mathrm{LiCl}$ aqueous solution by decantation, the viscous oil was dried in vacuo at $80{ }^{\circ} \mathrm{C}$ for $24 \mathrm{~h}$ to give poly( $N$-glycidyl- $N$ '-methylimidazolium bis(trifluoromethanesulfonyl)imide) (poly(ECH-MeIm $\left.{ }^{+} \mathrm{TFSI}^{-}\right)$) as a transparent viscous oil (Fig. 5(c) shows a macroscopic view). The predicted value of $M_{\mathrm{n}}$ for poly(ECH-MeIm ${ }^{+} \mathrm{TFSI}^{-}$) was 5500 . Similarly, poly $\left(N\right.$-glycidyl- $N^{\prime}$-methylimidazolium tetrafluoroborate) (poly(ECH-MeIm $\left.{ }^{+} \mathrm{BF}_{4}^{-}\right)$) was also produced via the anion exchange of poly $\left(\mathrm{ECH}-\mathrm{MeIm}^{+} \mathrm{Cl}^{-}\right)$with $\mathrm{LiBF}_{4}$. Fig. 2 shows selected ${ }^{1} \mathrm{H}$ NMR spectra of (a) poly $\left(\mathrm{ECH}-\mathrm{MeIm}^{+} \mathrm{Cl}^{-}\right)$, (b) poly $\left(\mathrm{ECH}-\mathrm{MeIm}^{+} \mathrm{TFSI}^{-}\right)$and (c) poly(ECH-MeIm ${ }^{+} \mathrm{BF}_{4}{ }^{-}$).

The proton signals of the imidazolium ring shifted to the higher magnetic field after the anion exchange reaction, whilst keeping the integration ratios of the imidazolium protons and the main chain protons constant. These observations are in good agreement with the fact that the proton signals of the imidazolium ring of $\left[\mathrm{EMIm}^{+}\right]\left[\mathrm{TFSI}^{-}\right]$are in a higher magnetic
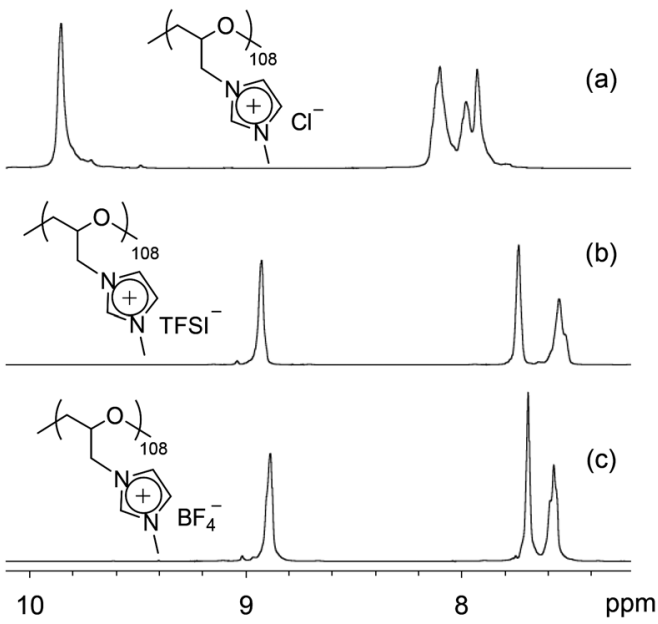

Fig. 2 Selected ${ }^{1} \mathrm{H}$ NMR spectra of (a) poly $\left(\mathrm{ECH}-\mathrm{Melm}^{+} \mathrm{Cl}^{-}\right)\left(M_{\text {n(calc) }}=\right.$ 18900 , and DP $=108)$, (b) poly $\left(\mathrm{ECH}-\mathrm{Melm}^{+} \mathrm{TFSI}^{-}\right)\left(M_{\mathrm{n} \text { (calc) }}=45400\right.$, and $\mathrm{DP}=108)$, and (c) poly $\left(\mathrm{ECH}-\mathrm{Melm}^{+} \mathrm{BF}_{4}^{-}\right)\left(M_{\text {n(calc })}=24500\right.$, and $\mathrm{DP}=$ 108), as described in Fig. S1(a), S2(a), and S3(a), $\dagger$ respectively (recorded in DMSO- $d_{6}$ at $27^{\circ} \mathrm{C}$ ).

field compared to those of $\left[\mathrm{EMIm}^{+}\right]\left[\mathrm{Cl}^{-}\right]$(Fig. S9†). These results suggest that the poly(ECH-MeIm $\left.{ }^{+} \mathrm{TFSI}^{-}\right)$and the poly $\left(\mathrm{ECH}-\mathrm{MeIm}^{+} \mathrm{BF}_{4}^{-}\right)$were successfully produced via the anion exchange reactions.

Furthermore, anion exchange was conducted for poly $\left(\mathrm{ECH}-\mathrm{MeIm}^{+} \mathrm{Cl}^{-}\right)$samples of varied MWs ((a) $M_{\mathrm{n} \text { (calc) }}=1900$, and DP = 11; (b) $M_{\mathrm{n} \text { (calc) }}=5800$, and DP = 33; and (c) $M_{\mathrm{n} \text { (calc) }}=$ 16200 , and DP $=92$ ) which were obtained from poly $(\mathrm{ECH})$ samples of different MWs. Similarly, tacky oil products were formed through anion exchange with LiTFSI. NMR analyses of the obtained oily products (Fig. S11 $\dagger$ ) confirmed that the TFSI anions were introduced to the poly $\left(\mathrm{ECH}-\mathrm{MeIm}^{+} \mathrm{Cl}^{-}\right)$samples to yield poly(ECH-MeIm ${ }^{+} \mathrm{TFSI}^{-}$) samples, irrespective of MW. In addition, C-F coupling was observed in the ${ }^{13} \mathrm{C}$ NMR spectra in Fig. S2(b), $\dagger$ indicating the $\mathrm{CF}_{3}$ carbon of the TFSI anion. To summarize, anion exchanges were conducted successfully.

\section{Fundamental properties of cationic polyethers}

Next, the solubility of poly(ECH), poly $\left(\mathrm{ECH}-\mathrm{MeIm}^{+} \mathrm{Cl}^{-}\right)$, poly (ECH-MeIm ${ }^{+} \mathrm{TFSI}^{-}$) and poly $\left(\mathrm{ECH}-\mathrm{MeIm}^{+} \mathrm{BF}_{4}{ }^{-}\right)$, as shown in Fig. 2, was studied and the results are summarized in Table 1. Poly(ECH) dissolves in ordinary organic solvents including toluene and THF. In contrast, poly $\left(\mathrm{ECH}-\mathrm{MeIm}^{+} \mathrm{Cl}^{-}\right)$is soluble only in polar solvents (e.g., $\mathrm{H}_{2} \mathrm{O}, \mathrm{MeOH}$ and DMSO), and therefore is proven to be a highly polar material. Poly (ECH-MeIm ${ }^{+} \mathrm{TFSI}^{-}$) is soluble in mid-polar solvents such as acetone, $\mathrm{CH}_{3} \mathrm{CN}$, THF and DMF, while it is insoluble in both non-polar and highly polar solvents. Poly $\left(\mathrm{ECH}-\mathrm{MeIm}^{+} \mathrm{BF}_{4}^{-}\right)$ appears to have limited solubility; the polymer is soluble in only $\mathrm{H}_{2} \mathrm{O}$ and aprotic polar solvents.

The miscibility of ionic liquids with water or organic solvents changes with a side chain on the cation and with the choice of anion. More specifically, $\left[\mathrm{EMIm}^{+}\right]\left[\mathrm{TFSI}^{-}\right]$is hydrophobic, while $\left[\mathrm{EMIm}^{+}\right]\left[\mathrm{Cl}^{-}\right]$and $\left[\mathrm{EMIm}^{+}\right]\left[\mathrm{BF}_{4}^{-}\right]$are hydrophilic. 
Table 1 Solubility of poly $(\mathrm{ECH})\left(M_{\mathrm{n}}=10000, M_{\mathrm{w}} / M_{\mathrm{n}}=1.13\right.$, and DP $=108$; Table S1, run 7†), poly $\left(\mathrm{ECH}-\mathrm{Melm}^{+} \mathrm{Cl}^{-}\right)\left(M_{\mathrm{n}(\mathrm{calc})}=18900\right.$, and $\left.\mathrm{DP}=108\right)$, poly $\left(\mathrm{ECH}-\mathrm{Melm}^{+} \mathrm{TFSI}^{-}\right)\left(M_{\mathrm{n} \text { (calc) }}=45400\right.$, and $\left.\mathrm{DP}=108\right)$ and poly $\left(\mathrm{ECH}^{-} \mathrm{Melm}^{+} \mathrm{BF}_{4}{ }^{-}\right)\left(M_{\mathrm{n} \text { (calc) }}=24500\right.$, and DP $\left.=108\right)$, as shown in Fig. 2

\begin{tabular}{lllll}
\hline & Poly(ECH) & Poly $\left(\mathrm{ECH}-\mathrm{MeIm}^{+} \mathrm{Cl}^{-}\right)$ & Poly $\left(\mathrm{ECH}-\mathrm{MeIm}^{+} \mathrm{TFSI}^{-}\right)$ & ${\text {Poly }\left(\mathrm{ECH}^{-} \mathrm{MeIm}{ }^{+} \mathrm{BF}_{4}{ }^{-}\right)}$ \\
\hline$n$-Hexane & $\times$ & $\times$ & $\times$ & $\times$ \\
Toluene & Soluble & $\times$ & $\times$ & $\times$ \\
$\mathrm{CHCl}_{3}$ & Soluble & $\times$ & $\times$ & $\times$ \\
$\mathrm{THF}$ & Soluble & $\times$ & Soluble & $\times$ \\
$\mathrm{CH}_{3} \mathrm{CN}$ & Soluble & $\times$ & Soluble & Soluble \\
Acetone & $\times$ & $\times$ & Soluble & $\times$ \\
$\mathrm{MeOH}$ & $\times$ & Soluble & $\times$ & $\times$ \\
$\mathrm{H}_{2} \mathrm{O}$ & $\times$ & $\times$ & Soluble \\
DMF & Soluble & $\times$ & Soluble & Soluble \\
DMSO & Soluble & Soluble & Soluble & Soluble
\end{tabular}

The solubility of these cationic polyethers might be influenced by the choice of anion. It is noteworthy that the cationic polyethers are miscible with various ionic liquids; the results are detailed below.

The thermal properties of the cationic polyethers were studied. Fig. 3 illustrates the DSC thermograms of poly $(\mathrm{ECH})$, poly $\left(\mathrm{ECH}-\mathrm{MeIm}^{+} \mathrm{Cl}^{-}\right)$, poly $\left(\mathrm{ECH}-\mathrm{MeIm}^{+} \mathrm{TFSI}^{-}\right)$, and poly $\left(\right.$ ECH-MeIm $\left.{ }^{+} \mathrm{BF}_{4}{ }^{-}\right)$, as depicted in Fig. 2 and Table 1. As expected, poly $(\mathrm{ECH})$ had the lowest glass transition point $\left(T_{\mathrm{g}}=\right.$ $\left.-45{ }^{\circ} \mathrm{C}\right)$. The dry poly $\left(\mathrm{ECH}-\mathrm{MeIm}^{+} \mathrm{Cl}^{-}\right)$shown in Fig. 5(a) appeared as a brittle resin. To prove this speculation, its glass transition point was higher than room temperature $\left(T_{\mathrm{g}}=\right.$ $90{ }^{\circ} \mathrm{C}$ ). This result indicates that the ionic interaction and the hydrogen bonding between the ionic groups and polyether chain decreased the mobility of the polymer. The poly $\left(\mathrm{ECH}-\mathrm{MeIm}^{+} \mathrm{TFSI}^{-}\right)$has a glass transition point at $-12{ }^{\circ} \mathrm{C}$ and no melting point. The macroscopic view shown in Fig. 5(c) indicates that poly $\left(\mathrm{ECH}-\mathrm{MeIm}^{+} \mathrm{TFSI}^{-}\right)$is a liquid rubber, and the DSC data supports this idea. The $T_{\mathrm{g}}$ of the poly $\left(\mathrm{ECH}-\mathrm{MeIm}^{+} \mathrm{TFSI}^{-}\right)$is comparable with that of poly( $N$-glycidyl$N^{\prime}$-methylimidazolium bis(trifluoromethanesulfonyl)imide) $\left(T_{\mathrm{g}}=-14{ }^{\circ} \mathrm{C}\right)$ reported by Baker et al. ${ }^{36}$ The DSC thermogram

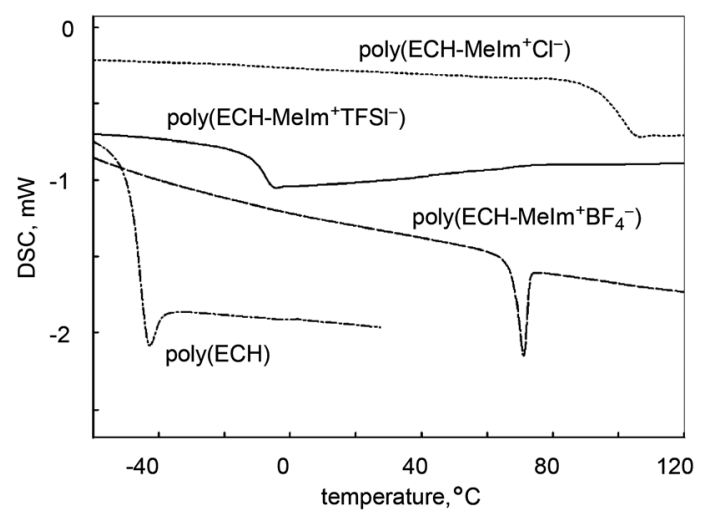

Fig. 3 DSC thermograms (heating steps) of poly $(\mathrm{ECH})\left(M_{\mathrm{n}}=10000\right.$, $M_{\mathrm{w}} / M_{\mathrm{n}}=1.13$, and DP = 108; Table S1, run 7†), poly $\left(\mathrm{ECH}-\mathrm{Melm}^{+} \mathrm{Cl}^{-}\right)$ $\left(M_{\text {n(calc })}=18900\right.$, and DP $\left.=108\right)$, poly $\left(E C H-M e l m^{+} \mathrm{TFSI}^{-}\right)\left(M_{\text {n(calc })}=\right.$ 45400 , and $\mathrm{DP}=108)$, and poly $\left(\mathrm{ECH}-\mathrm{Melm}^{+} \mathrm{BF}_{4}{ }^{-}\right)\left(M_{\mathrm{n} \text { (calc) }}=24500\right.$, and DP $=108$ ), as described in Fig. 2 and Table 1 (determined under $N_{2}$, at $10{ }^{\circ} \mathrm{C} \mathrm{min}^{-1}$ for each step). of poly $\left(\mathrm{ECH}-\mathrm{MeIm}{ }^{+} \mathrm{BF}_{4}{ }^{-}\right)$shows a glass transition at $65^{\circ} \mathrm{C}$, not a phase transition, which appears to be like a melting point peak. It is interesting that a very large relaxation of the constrained poly $\left(\mathrm{ECH}-\mathrm{MeIm}^{+} \mathrm{BF}_{4}^{-}\right)$was observed at the glass transition point, but we do not have any experimental data to explain this phenomena. To summarize, all of the cationic polyethers are amorphous polymers, in which the glass transition points are dependent on the counter anions.

Furthermore, the thermal stability of the cationic polyethers was studied using TG/DTA measurement. Fig. 4 summarizes the DTA analysis under an $\mathrm{N}_{2}$ stream for poly(ECH), poly $\left(\mathrm{ECH}-\mathrm{MeIm}^{+} \mathrm{Cl}^{-}\right)$, poly $\left(\mathrm{ECH}-\mathrm{MeIm}^{+} \mathrm{TFSI}^{-}\right)$, and poly $\left(\mathrm{ECH}-\mathrm{MeIm}^{+} \mathrm{BF}_{4}{ }^{-}\right)$, which were described in Fig. 3. The poly $(\mathrm{ECH})$ started thermal decomposition above $300{ }^{\circ} \mathrm{C}$ and the $5 \%$ thermal decomposition temperature $\left(T_{\mathrm{d} 5 \%}\right)$ was $330{ }^{\circ} \mathrm{C}$. The $T_{\mathrm{d}}$ of ethylmethylimidazolium bromide and $\left[\mathrm{BMIm}^{+}\right]\left[\mathrm{Cl}^{-}\right]$ are reported to be around $220^{\circ} \mathrm{C}$ and $240{ }^{\circ} \mathrm{C}$, respectively, and the low thermal stability may be attributed to the nucleophilic attack of the halide anion on the imidazolium ring. It is interesting that $T_{\mathrm{d} 5 \%}$ of the poly $\left(\mathrm{ECH}-\mathrm{MeIm}^{+} \mathrm{Cl}^{-}\right)$is as high as $298^{\circ} \mathrm{C}$. At first, the water confined in the poly $\left(\mathrm{ECH}-\mathrm{MeIm}^{+} \mathrm{Cl}^{-}\right)$ started to evaporate at $60{ }^{\circ} \mathrm{C}$. Then, the weight of the poly

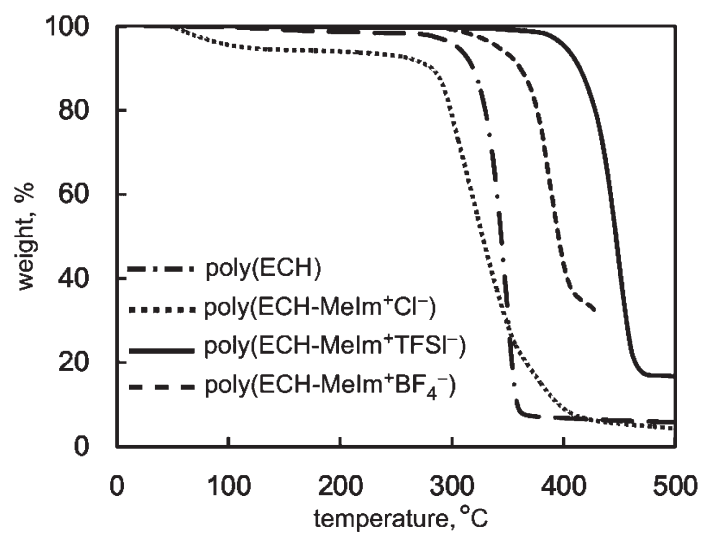

Fig. 4 TG/DTA thermograms of poly $(\mathrm{ECH})\left(M_{\mathrm{n}}=10000, M_{\mathrm{w}} / M_{\mathrm{n}}=1.13\right.$, and $\mathrm{DP}=108$; Table S1, run 7†), poly $\left(\mathrm{ECH}-\mathrm{Melm}^{+} \mathrm{Cl}^{-}\right)\left(M_{\text {n(calc) }}=18900\right.$, and $\mathrm{DP}=108)$, poly $\left(\mathrm{ECH}-\mathrm{Melm}^{+} \mathrm{TFSI}^{-}\right)\left(M_{\mathrm{n} \text { (calc) }}=45400\right.$, and DP $\left.=108\right)$, and poly $\left(\mathrm{ECH}-\mathrm{Melm}^{+} \mathrm{BF}_{4}{ }^{-}\right)\left(M_{\mathrm{n} \text { (calc) }}=24500\right.$, and $\left.\mathrm{DP}=108\right)$, as described in Fig. 2, Fig. 3 and Table 1 (determined under $\mathrm{N}_{2}$, at $10{ }^{\circ} \mathrm{C}$ $\mathrm{min}^{-1}$ for each). 
$\left(\mathrm{ECH}-\mathrm{MeIm}^{+} \mathrm{Cl}^{-}\right)$became almost constant above $100{ }^{\circ} \mathrm{C}$. Finally, the poly $\left(\mathrm{ECH}-\mathrm{MeIm}^{+} \mathrm{Cl}^{-}\right)$started to decompose around $300{ }^{\circ} \mathrm{C} .{ }^{41}$ In contrast, Stoica et al. reported that the partially cationized polyether started to decompose at $220{ }^{\circ} \mathrm{C} .{ }^{32}$ This can be explained by the idea that densely branched ionic liquid groups were stabilized by each other and by the polyether chain. This phenomenon was also observed not only in another polymerized ionic liquid but also in another type of ionic liquid complex. ${ }^{4,43}$ Poly $\left(\mathrm{ECH}^{4} \mathrm{MeIm}^{+} \mathrm{TFSI}^{-}\right)$is highly stable at elevated temperatures. The $T_{\mathrm{d} 5 \%}$ of $\left[\mathrm{EMIm}^{+}\right]\left[\mathrm{TFSI}^{-}\right]$is reported to be above $400{ }^{\circ} \mathrm{C}$. Similar to the case of the $T_{\mathrm{d} 5 \%}$ of poly( $N$-glycidyl- $N$ '-butyllimidazolium bis(trifluoromethanesulfonyl)imide) reported by Baker et al., ${ }^{36}$ the $T_{\mathrm{d} 5 \%}$ of the poly

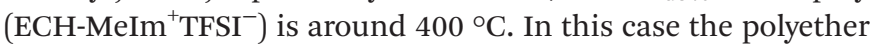
chain was thermally stabilized by the $\mathrm{MeIm}^{+} \mathrm{TFSI}^{-}$group. It is interesting to note that the $T_{\mathrm{d} 5 \%}$ of the poly(ECH-MeIm ${ }^{+} \mathrm{BF}_{4}{ }^{-}$) is also high at around $350{ }^{\circ} \mathrm{C}$. Note, that the $T_{\mathrm{d} 5 \%}$ of

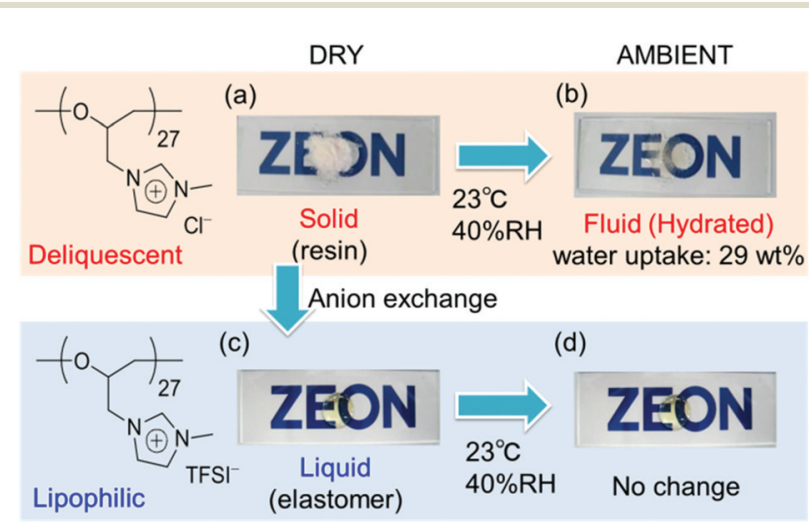

Fig. 5 Macroscopic views of (a) poly $\left(\mathrm{ECH}-\mathrm{Melm}^{+} \mathrm{Cl}^{-}\right)\left(M_{\text {n(calc) }}=4700\right.$, and $D P=27)$ prepared from poly $(E C H)\left(M_{n}=2500\right.$, and $D P=27$; Table S1, run $6 \dagger)$ kept under a dry atmosphere, (b) poly $\left(\mathrm{ECH}-\mathrm{Melm}^{+} \mathrm{Cl}^{-}\right)$ $\left(M_{\text {n(calc })}=4700\right.$, and DP $\left.=27\right)$ after being exposed to air $\left(23^{\circ} \mathrm{C}\right.$, and $40 \%$ $\mathrm{RH})$ for $30 \mathrm{~min}$, (c) the dry poly $\left(\mathrm{ECH}-\mathrm{Melm}^{+} \mathrm{TFSI}^{-}\right)\left(M_{\text {n(calc })}=11300\right.$, and $\mathrm{DP}=27)$ prepared via anion exchange with poly $\left(\mathrm{ECH}-\mathrm{Melm}^{+} \mathrm{Cl}^{-}\right)\left(\mathrm{M}_{\text {n(calc) }}=\right.$ 4700 , and DP $=27)$ and (d) poly $\left(\mathrm{ECH}-\mathrm{Melm}^{+} \mathrm{TFSI}^{-}\right)\left(M_{\text {n(calc }}=11300\right.$, and $\mathrm{DP}=27)$ after being exposed to air $\left(23^{\circ} \mathrm{C}\right.$, and $\left.40 \% \mathrm{RH}\right)$ for $24 \mathrm{~h}$.
$\left[\mathrm{EMIm}^{+}\right]\left[\mathrm{BF}_{4}^{-}\right]$was reported at around $350{ }^{\circ} \mathrm{C}$. We conducted TG-DTA analysis of commercially available $\left[\mathrm{EMIm}^{+}\right]\left[\mathrm{BF}_{4}{ }^{-}\right]$ without purification, and found that the $T_{\mathrm{d} 5 \%}$ was $265{ }^{\circ} \mathrm{C}$. Bearing the thermal stabilities of poly $(\mathrm{ECH})$ and $\left[\mathrm{EMIm}^{+}\right]\left[\mathrm{BF}_{4}{ }^{-}\right]$ in mind, it can be said that the polyether chain and the MeIm ${ }^{+} \mathrm{BF}_{4}{ }^{-}$group of poly $\left(\mathrm{ECH}-\mathrm{MeIm}{ }^{+} \mathrm{BF}_{4}{ }^{-}\right)$stabilize each other. To summarize, the cationic polyethers are thermally stable.

\section{Deliquescent nature of poly $\left(\mathrm{ECH}-\mathrm{MeIm}^{+} \mathrm{Cl}^{-}\right)$}

One of the most significant properties of poly $\left(\mathrm{ECH}-\mathrm{MeIm}^{+} \mathrm{Cl}^{-}\right)$ is a deliquescence feature coming from its high polarity. Fig. 5 illustrates macroscopic views of (a) poly $\left(\mathrm{ECH}-\mathrm{MeIm}^{+} \mathrm{Cl}^{-}\right)$ $\left(M_{\mathrm{n}(\mathrm{calc})}=4700\right.$, and DP $=27$; as described in Table 2 below $)$ which was kept under a dry atmosphere, and (b) the hydrated poly $\left(\mathrm{ECH}-\mathrm{MeIm}^{+} \mathrm{Cl}^{-}\right)$after being exposed to air under ambient conditions $\left(23^{\circ} \mathrm{C}\right.$, and $40 \%$ relative humidity $(\mathrm{RH})$ ) for $30 \mathrm{~min}$. The poly $\left(\mathrm{ECH}-\mathrm{MeIm}^{+} \mathrm{Cl}^{-}\right)$appears as an amorphous resin when it is completely dry (Fig. 5(a)). In general, polyethers, aside from crystalline poly(ethylene oxide), are recognized as elastomers. It is presumed that the ionic interaction and hydrogen bonding between the ionic groups strongly suppressed the molecular mobility of the polymer chain, and as a result, increased the glass transition point of the poly $\left(\mathrm{ECH}-\mathrm{MeIm}^{+} \mathrm{Cl}^{-}\right)$. When the poly $\left(\mathrm{ECH}-\mathrm{MeIm}^{+} \mathrm{Cl}^{-}\right)$was exposed to air, it absorbed large amounts of moisture to be hydrated under relatively dry conditions $\left(23^{\circ} \mathrm{C}, 40 \% \mathrm{RH}\right.$, and a water uptake $=29 \mathrm{wt} \%)$. The water-absorption process took less than 30 min when $0.5 \mathrm{~g}$ of the polymer powder was in contact with air. First, the surface of the polymer powder absorbed moisture to become wet. Then, the polymer continued to absorb water in air to change its appearance to something like a viscous fluid. Finally, the hydration of the polymer saturated to become an aqueous solution where the viscosity seemed very low (Fig. 5(b)). This result suggests that poly $\left(\mathrm{ECH}-\mathrm{MeIm}^{+} \mathrm{Cl}^{-}\right)$ is a deliquescent polymer. This character is supposed to be derived mainly from the specific property of the imidazolium chloride-based ionic liquid moiety; $\left[\mathrm{EMIm}^{+}\right]\left[\mathrm{Cl}^{-}\right]$exhibits a high moisture absorption capacity. In addition, the hydro-

Table 2 Water uptake and ionic conductivity of cationic polyether ${ }^{a}$

\begin{tabular}{|c|c|c|c|c|c|c|}
\hline Run & $\mathrm{DP}$ & $\mathrm{RH}^{b}(\%)$ & Appearance & Water uptake $^{c}(\mathrm{wt} \%)$ & {$\left[\mathrm{H}_{2} \mathrm{O}\right] /[\text { cation }]^{d}$} & Ionic conductivity $^{c}\left(\mathrm{~S} \mathrm{~cm}^{-1}\right)$ \\
\hline 1 & 27 & 0 & Solid & 0 & 0 & $<10^{-10}$ \\
\hline 2 & 27 & 20 & Liquid & 18 & 1.8 & $5.7 \times 10^{-4}$ \\
\hline 3 & 27 & 40 & Liquid & 29 & 2.8 & $2.7 \times 10^{-3}$ \\
\hline 4 & 27 & 60 & Liquid & 45 & 4.4 & $8.4 \times 10^{-3}$ \\
\hline 5 & 27 & 80 & Liquid & 72 & 7.0 & $1.8 \times 10^{-2}$ \\
\hline 6 & 108 & 0 & Solid & 0 & 0 & $<10^{-10}$ \\
\hline 7 & 108 & 20 & Liquid & 18 & 1.8 & $5.1 \times 10^{-4}$ \\
\hline 8 & 108 & 40 & Liquid & 29 & 2.8 & $3.2 \times 10^{-3}$ \\
\hline 9 & 108 & 60 & Liquid & 44 & 4.3 & $5.9 \times 10^{-3}$ \\
\hline 10 & 108 & 80 & Liquid & 69 & 6.7 & $1.6 \times 10^{-2}$ \\
\hline
\end{tabular}

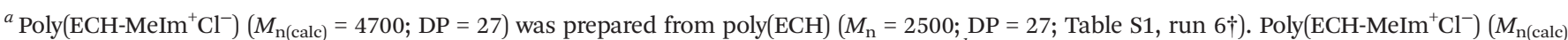

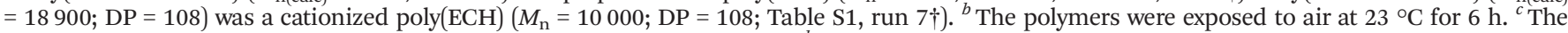
ionic conductivity was determined using impedance spectroscopy at $20^{\circ} \mathrm{C}$. ${ }^{d}$ Mole ratio. 
philic polyether chain might play an important role in the deliquescent nature of poly $\left(\mathrm{ECH}-\mathrm{MeIm}^{+} \mathrm{Cl}^{-}\right)$.

To the best of our knowledge, not much has been reported regarding deliquescent polymers. ${ }^{44}$ The water-uptake behavior, solubility and hydrophilicity of various poly(IL)s have been thoroughly studied in the past, however they were not deliquescent. $^{5-8}$ For instance, we synthesized poly(methylvinylimidazolium iodide) according to the literature and exposed it to air under ambient conditions $\left(23{ }^{\circ} \mathrm{C}\right.$, and $60 \%$ $\mathrm{RH})$. It was confirmed to be hygroscopic but not deliquescent. Highly hygroscopic poly(acrylic acid) sodium salt $\left(M_{\mathrm{w}}=5100\right)$ absorbed moisture in air to a certain extent $\left(23{ }^{\circ} \mathrm{C}\right.$, and $60 \%$ $\mathrm{RH}$; water uptake $=55 \mathrm{wt} \%$ ) but did not display any fluidity. This suggests that poly(acrylic acid) sodium salt is not deliquescent but just hygroscopic under less-humid conditions. A partially cationized polyether was reported to swell in water, but it was not deliquescent. ${ }^{32,33}$ In contrast, fully cationized polyethers with imidazolium halide groups such as the low MW poly $\left(\mathrm{ECH}-\mathrm{MeIm}^{+} \mathrm{Cl}^{-}\right)\left(M_{\mathrm{n}(\mathrm{calc})}=4700\right.$, and DP $\left.=27\right)$, the high MW one $\left(M_{\mathrm{n}(\mathrm{calc})}=18900\right.$, and DP $\left.=108\right)$ and $\operatorname{poly}(N$-glycidyl- $N$-methylimidazolium iodide $)\left(M_{\mathrm{n}(\mathrm{calc})}=7200\right.$, and $\mathrm{DP}=$ 27) absorbed moisture to become fully plasticized and fluid $\left(23{ }^{\circ} \mathrm{C}\right.$, and $60 \% \mathrm{RH}$; water uptake $=45 \mathrm{wt} \%, 44 \mathrm{wt} \%$ and $14 \mathrm{wt} \%$, respectively). Note that poly(acrylic acid) sodium salt and poly(ethylene oxide) were reported to absorb small amounts of moisture under relatively dry conditions $\left(30{ }^{\circ} \mathrm{C}\right.$, and $40 \% \mathrm{RH}$; water uptake $<5 \mathrm{wt} \%),{ }^{45}$ in contrast to the poly $\left(\mathrm{ECH}-\mathrm{MeIm}^{+} \mathrm{Cl}^{-}\right)$which is deliquescent under similar conditions.

With regards to the contribution of the counter anion to deliquescence, poly(ECH-MeIm $\left.{ }^{+} \mathrm{TFSI}^{-}\right)$is hydrophobic $\left(23{ }^{\circ} \mathrm{C}\right.$, and $40 \% \mathrm{RH}$; water uptake $<0.2 \mathrm{wt} \%$ ). The macroscopic view of the completely dry poly(ECH-MeIm ${ }^{+}$TFSI $^{-}$) (Fig. 5(c)) didn't change after being exposed to air (Fig. 5(d)), indicating a low water absorbency for poly $\left(\mathrm{ECH}-\mathrm{MeIm}^{+} \mathrm{TFSI}^{-}\right)$. Poly $\left(\mathrm{ECH}-\mathrm{MeIm}{ }^{+} \mathrm{BF}_{4}{ }^{-}\right)\left(M_{\mathrm{n} \text { (calc) }}=18900\right.$, and DP $\left.=108\right)$ is hygroscopic $\left(23{ }^{\circ} \mathrm{C}\right.$, and $40 \% \mathrm{RH}$; water uptake $=3.3 \mathrm{wt} \%, 23{ }^{\circ} \mathrm{C}$, and $60 \% \mathrm{RH}$; water uptake $=6.8 \mathrm{wt} \%$ ) but not deliquescent. To summarize, the deliquescent character of the present cationic polyethers with imidazolium halide groups is supposed to be derived from the combination of both the imidazolium chloride groups and the polyether chain. ${ }^{46}$

The relationship between water uptake and $M_{\mathrm{n}}$ of poly $\left(\mathrm{ECH}-\mathrm{MeIm}^{+} \mathrm{Cl}^{-}\right)$was investigated to understand the effect of the polymer's MW on the hydration behavior. We prepared $\operatorname{poly}\left(\mathrm{ECH}-\mathrm{MeIm}^{+} \mathrm{Cl}^{-}\right)$with the following $\mathrm{MWs}\left(M_{\mathrm{n}(\text { calc })}=2300\right.$, and DP $=13 ; M_{\mathrm{n}(\text { calc })}=9400$, and DP $=54 ; M_{\mathrm{n}(\text { calc })}=18800$, and $\mathrm{DP}=108)$ and allowed them to be exposed to air $\left(0.5 \mathrm{~g}, 23^{\circ} \mathrm{C}\right.$, and $40 \% \mathrm{RH})$. Similar to the case of the poly $\left(\mathrm{ECH}-\mathrm{MeIm}^{+} \mathrm{Cl}^{-}\right)$ stated above $\left(M_{\mathrm{n} \text { (calc) }}=4700\right.$ and $\mathrm{DP}=27$, at $23{ }^{\circ} \mathrm{C}$ and $40 \%$ $\mathrm{RH}$; water uptake $=29 \mathrm{wt} \%$ ), the water-absorption process only needed 30-60 min. The hydration rate of each polymer will not be discussed here, because the surface area of each polymer powder seemed unclear. However, the saturated water uptake of each polymer was verified to be almost identical at around $29 \mathrm{wt} \%$ (water uptake $=30 \mathrm{wt} \%$ for $M_{\mathrm{n}(\text { calc })}=2300,30 \mathrm{wt} \%$ for
$M_{\mathrm{n}(\mathrm{calc})}=9400$, and $29 \mathrm{wt} \%$ for $\left.M_{\mathrm{n}(\mathrm{calc})}=18800\right)$. It can be said that the water uptake depends not on the molecular weight but on the molecular structure of the repeating units.

\section{Effects of hydration on the properties of poly $\left(\mathrm{ECH}-\mathrm{MeIm}^{+} \mathrm{Cl}^{-}\right)$}

In order to obtain information regarding the effects of hydration on the thermal properties of the cationic polyethers, DSC measurements of poly $\left(\mathrm{ECH}-\mathrm{MeIm}^{+} \mathrm{Cl}^{-}\right)$, the hydrated poly $\left(\mathrm{ECH}-\mathrm{MeIm}^{+} \mathrm{Cl}^{-}\right), \quad \operatorname{poly}\left(\mathrm{ECH}_{60}\right.$-ran- $\left(N\right.$-glycidyl- $N^{\prime}$-methylimidazolium chloride $\left.)_{40}\right)$ (poly $\left(\mathrm{ECH}-\mathrm{MeIm}^{+} \mathrm{Cl}^{-}{ }_{40 \%}\right)$ ) and the hydrated poly $\left(\mathrm{ECH}-\mathrm{MeIm}{ }^{+} \mathrm{Cl}^{-}{ }_{40 \%}\right)$ were conducted next (Fig. 6). The dry poly $\left(\mathrm{ECH}-\mathrm{MeIm}^{+} \mathrm{Cl}^{-}\right)$shown in Fig. 5(a) appeared to be a brittle resin. As evidence of the speculation, its glass transition point was shown to be higher than room temperature $\left(T_{\mathrm{g}}=90{ }^{\circ} \mathrm{C}\right.$; Fig. 6(a)). On the other hand, it is interesting that the hydrated poly(ECH-MeIm $\left.{ }^{+} \mathrm{Cl}^{-}\right)\left(23{ }^{\circ} \mathrm{C}, 40 \%\right.$ $\mathrm{RH}$, water uptake $=29 \mathrm{wt} \%$, and $\left[\mathrm{H}_{2} \mathrm{O}\right] /\left[\mathrm{MeIm}^{+} \mathrm{Cl}^{-}\right.$group $]=$ $2.8 \mathrm{~mol} / \mathrm{mol}$, in reference to Table 3 ) possessed neither a glass transition nor a phase transition between $-60{ }^{\circ} \mathrm{C}$ and $80{ }^{\circ} \mathrm{C}$ (Fig. 6(b)). ${ }^{47}$ This suggests that the confined water does not freeze, and that the hydrated poly $\left(\mathrm{ECH}-\mathrm{MeIm}^{+} \mathrm{Cl}^{-}\right)$can be regarded as an elastomer with a very low glass transition point. More specifically, the absorbed water might have a strong interaction with the $\mathrm{MeIm}^{+} \mathrm{Cl}^{-}$group of the present polymer
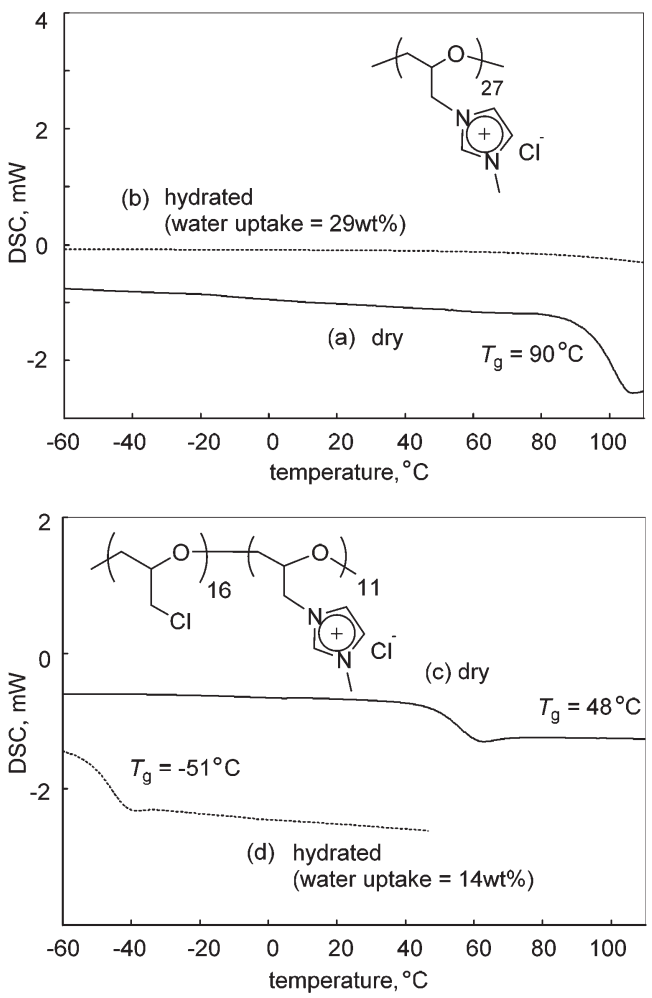

Fig. 6 DSC thermograms (heating steps) of (a) poly $\left(\mathrm{ECH}-\mathrm{Melm}^{+} \mathrm{Cl}^{-}\right)$, (b) the hydrated poly $\left(\mathrm{ECH}-\mathrm{Melm}^{+} \mathrm{Cl}^{-}\right.$) (after being exposed to air $\left(23{ }^{\circ} \mathrm{C}\right.$, and $40 \% \mathrm{RH}$ ) for $30 \mathrm{~min}$ ), (c) poly (ECH-Melm ${ }^{+} \mathrm{Cl}^{-}{ }_{40 \%}$ ) and (d) the hydrated poly $\left(\mathrm{ECH}-\mathrm{MeIm}^{+} \mathrm{Cl}^{-}{ }_{40 \%}\right)$ after being exposed to air $\left(23^{\circ} \mathrm{C}\right.$, and $40 \% \mathrm{RH}$ ) for $30 \mathrm{~min}$ (determined under $\mathrm{N}_{2}$, at $10^{\circ} \mathrm{C} \mathrm{min}^{-1}$ for each step). 
Table 3 Water uptake and ionic conductivity of the partially cationized polyethers obtained from poly $(\mathrm{ECH})\left(\mathrm{M}_{\mathrm{n}}=2500\right.$, and DP = 27; Table $\mathrm{S} 1$, run $6 \dagger)$ under varied conditions ${ }^{a}$

\begin{tabular}{|c|c|c|c|c|c|c|}
\hline Ionization & $0 \mathrm{~mol} \%$ & $20 \mathrm{~mol} \%$ & $40 \mathrm{~mol} \%$ & $60 \mathrm{~mol} \%$ & $80 \mathrm{~mol} \%$ & $100 \mathrm{~mol} \%$ \\
\hline \multirow{3}{*}{$20 \%$} & 0 & 1.7 & 6.3 & 13 & 15 & 18 \\
\hline & 0 & 0.5 & 1.1 & 1.7 & 1.6 & 1.8 \\
\hline & $5.4 \times 10^{-10}$ & $1.3 \times 10^{-7}$ & $1.3 \times 10^{-6}$ & $1.0 \times 10^{-4}$ & $2.5 \times 10^{-4}$ & $5.7 \times 10^{-4}$ \\
\hline $40 \%$ & & 4.1 & 14 & 21 & 25 & 29 \\
\hline \multirow[t]{3}{*}{$60 \%$} & & 10 & 25 & 35 & 40 & 45 \\
\hline & & 3.0 & 4.4 & 4.6 & 4.4 & 4.4 \\
\hline & & $6.2 \times 10^{-4}$ & $2.4 \times 10^{-3}$ & $2.7 \times 10^{-3}$ & $4.5 \times 10^{-3}$ & $8.4 \times 10^{-3}$ \\
\hline \multirow[t]{3}{*}{$80 \%$} & & 22 & 43 & 59 & 66 & 72 \\
\hline & & 6.7 & 7.5 & 7.7 & 7.3 & 7.0 \\
\hline & & $2.3 \times 10^{-3}$ & $5.5 \times 10^{-3}$ & $5.9 \times 10^{-3}$ & $9.8 \times 10^{-3}$ & $1.8 \times 10^{-2}$ \\
\hline
\end{tabular}

${ }^{a}$ At $23{ }^{\circ} \mathrm{C} .{ }^{b}$ The ionic conductivity was measured using impedance spectroscopy at $20^{\circ} \mathrm{C}$.

and, as a result, the poly $\left(\mathrm{ECH}-\mathrm{MeIm}^{+} \mathrm{Cl}^{-}\right)$was plasticized by the water, while the water molecule became non-freezing.

The $40 \%$ cationized poly $(\mathrm{ECH})$, poly $\left(\mathrm{ECH}-\mathrm{MeIm}^{+} \mathrm{Cl}^{-}{ }_{40 \%}\right)$, was prepared from poly $(\mathrm{ECH})\left(M_{\mathrm{n}}=2500, M_{\mathrm{w}} / M_{\mathrm{n}}=1.20\right.$, and $\mathrm{DP}=27$; Table S1, run $6 \dagger)$. The dry poly $\left(\mathrm{ECH}-\mathrm{MeIm}^{+} \mathrm{Cl}^{-}{ }_{40 \%}\right)$ exhibited a glass transition point at $48{ }^{\circ} \mathrm{C}$ which is lower than that of the fully cationized polymer (Fig. 6(c)). This suggests a decrease of the ionic aggregation of the imidazolium groups and an increase in the molecular mobility of the chain. The hydrated poly $\left(\mathrm{ECH}-\mathrm{MeIm}^{+} \mathrm{Cl}^{-}{ }_{40 \%}\right)\left(23{ }^{\circ} \mathrm{C}\right.$, and $40 \% \mathrm{RH}$; water uptake $=14 \mathrm{wt} \%$, and $\left[\mathrm{H}_{2} \mathrm{O}\right] /\left[\mathrm{MeIm}^{+} \mathrm{Cl}^{-}\right.$group $]=2.4 \mathrm{~mol} / \mathrm{mol}$, in reference to Table 3 ) had a very low glass transition point at $-51{ }^{\circ} \mathrm{C}$, and didn't have a phase transition point relating to the fusion of $\mathrm{H}_{2} \mathrm{O}$ (Fig. 6(d)). This result also supports the hypothesis above.

We found that the hydrated poly $\left(\mathrm{ECH}-\mathrm{MeIm}^{+} \mathrm{Cl}^{-}\right)$was characterized to be highly conductive. Table 2 summarizes the water uptake and ionic conductivity of the hydrated poly $\left(\mathrm{ECH}-\mathrm{MeIm}^{+} \mathrm{Cl}^{-}\right)$samples measured using dielectric spectroscopy under various RHs (Fig. S12† shows selected Nyquist plots of the poly(ECH-MeIm $\left.{ }^{+} \mathrm{Cl}^{-}\right)$after being exposed to air with different RHs). Poly(ECH-MeIm ${ }^{+} \mathrm{Cl}^{-}$) is an insulator (conductivity $<10^{-10} \mathrm{~S} \mathrm{~cm}^{-1}$ ) if it is entirely dry. When the polymer was kept under humid conditions $\left(23^{\circ} \mathrm{C}\right.$, and $\left.80 \% \mathrm{RH}\right)$, the water uptake increased up to $72 \mathrm{wt} \%$ and the conductivity at $20^{\circ} \mathrm{C}$ also elevated up to $1.8 \times 10^{-2} \mathrm{~S} \mathrm{~cm}^{-1}$. To understand the effect of the incorporated water molecules on the ionic conductivity, the varied $\mathrm{RH}$ of the atmosphere was studied. Under relatively dry conditions $\left(23{ }^{\circ} \mathrm{C}\right.$, and $\left.20 \% \mathrm{RH}\right)$, the water uptake remained at $18 \mathrm{wt} \%$ and the conductivity at $20{ }^{\circ} \mathrm{C}$ was $5.4 \times 10^{-4} \mathrm{~S} \mathrm{~cm}^{-1}$. To roughly summarize, the water uptake increased with increasing $\mathrm{RH}$, while the conductivity also increased with increasing water uptake. In contrast, the molecular weight had little effect on the water-uptake and the ionic conductivity. The properties of the fully cationized poly $\left(\mathrm{ECH}-\mathrm{MeIm}^{+} \mathrm{Cl}^{-}\right)$samples with two different DPs are compared in Table 2. The water-uptake and the conductivity are dependent not on molecular weight but on RH.

Furthermore, we prepared cationized polyethers with different ionization ratios. Table 3 shows the $\mathrm{RH}$ dependence of the water uptake and the ionic conductivity of partially cationized polyethers. The $\left[\mathrm{H}_{2} \mathrm{O}\right] /[$ cation] ratio was dependent not on the cationization ratio but on the relative humidity, particularly when the ionization ratio and $\mathrm{RH}$ were not very low. The ionic conductivity was influenced by the $\left[\mathrm{H}_{2} \mathrm{O}\right] /[$ cation] ratio, while it was largely influenced by the water uptake. To provide an insight to these results, the water incorporated in the cationic polyethers appears to play an essential role in increasing the ionic conductivity. The origin of the high ionic conductivity of the hydrated polymers can be explained by a water-assisted transport mechanism that has been well studied for poly(IL)s and Nafions. ${ }^{11,12,48}$

\section{Miscibility of cationic polyethers and ionic liquids}

Cationic polyethers and ionic liquids are ionic materials. Thus far, the miscibility of ionic liquids and the properties of the formed ionic liquid mixtures have been well-studied. ${ }^{49-52}$ In general, ionic liquids are not highly soluble in organic solvents such as toluene or methanol, while they are miscible in each other. Polymer materials are less soluble in ionic liquids. In this part, we have studied the miscibility of the cationic polyethers in themselves and in ionic liquids.

At first, the miscibility of poly $\left(\mathrm{ECH}-\mathrm{MeIm}^{+} \mathrm{Cl}^{-}\right)$and poly $\left(\mathrm{ECH}-\mathrm{MeIm}^{+} \mathrm{TFSI}^{-}\right)$was investigated. A poly $\left(\mathrm{ECH}-\mathrm{MeIm}^{+} \mathrm{Cl}^{-}\right)$ solution in methanol was added dropwise into equimolar poly

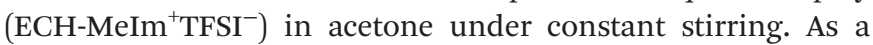
result, no precipitation was observed in the formed homogeneous solution. The organic solvents of the solution were evaporated at $50{ }^{\circ} \mathrm{C}$ for $24 \mathrm{~h}$ so that only a brittle transparent polymer, an equimolar mixture, remained behind. Fig. 7 shows selected ${ }^{1} \mathrm{H}$ NMR spectra of the poly $\left(\mathrm{ECH}-\mathrm{MeIm}^{+} \mathrm{Cl}^{-}\right)$, the poly $\left(\mathrm{ECH}-\mathrm{MeIm}^{+} \mathrm{TFSI}^{-}\right)$and the equimolar mixture of the 

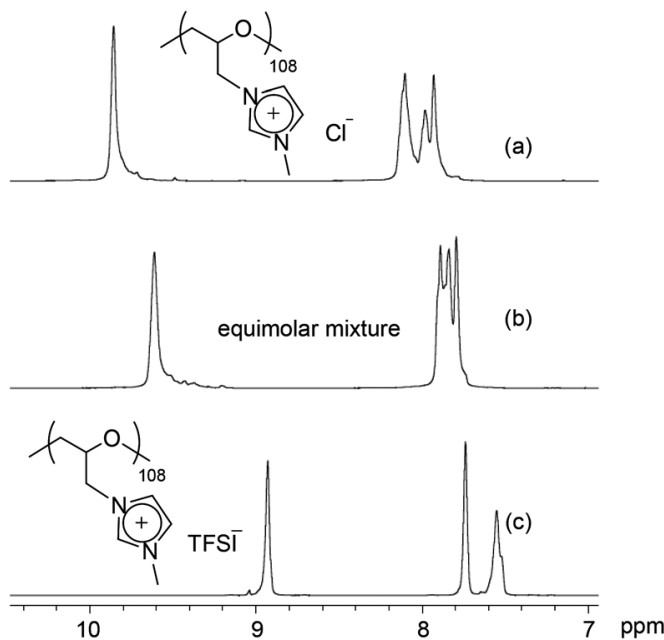

Fig. 7 Selected ${ }^{1} \mathrm{H}$ NMR spectra of poly $\left(\mathrm{ECH}-\mathrm{Melm}^{+} \mathrm{Cl}^{-}\right)\left(M_{\text {n(calc })}=\right.$ 18900 , and DP $=108)$, poly $\left(E C H-M_{\text {elm }}{ }^{+} \mathrm{TFSI}^{-}\right)\left(M_{\mathrm{n} \text { (calc })}=45400\right.$, and $\mathrm{DP}=108$ ) and the equimolar mixture of the two (recorded in DMSO- $d_{6}$ at $27^{\circ} \mathrm{C}$ )

two. It is interesting to note that the signals of the imidazolium protons of the equimolar mixture are observed between those of the poly(ECH-MeIm $\left.{ }^{+} \mathrm{Cl}^{-}\right)$and the poly $\left(\mathrm{ECH}-\mathrm{MeIm}^{+} \mathrm{TFSI}^{-}\right)$. If the equimolar mixture is just a mixture of the two polymers, four distinct proton signals from the poly $\left(\mathrm{ECH}-\mathrm{MeIm}^{+} \mathrm{Cl}^{-}\right)$and the poly$\left(\mathrm{ECH}-\mathrm{MeIm}^{+} \mathrm{TFSI}^{-}\right)$would be observable in the aromatic region. This strongly implies that the equimolar mixture was a uniform compound.

To understand further about the uniform compound (equimolar mixture), the thermal properties and the solubility were studied (a DSC thermogram of the mixture is depicted in Fig. S13†). Between $-20{ }^{\circ} \mathrm{C}$ and $110{ }^{\circ} \mathrm{C}$, only one glass transition point was observed at $37^{\circ} \mathrm{C}$. To put this into context, we note that the $T_{\mathrm{g}}$ of the poly $\left(\mathrm{ECH}-\mathrm{MeIm}^{+} \mathrm{Cl}^{-}\right)$and the poly

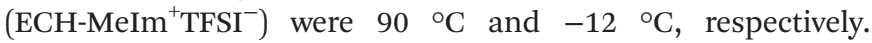
Furthermore, the solubility of the mixture was studied. Table S2 $\uparrow$ summarizes the solubility of the poly $\left(\mathrm{ECH}-\mathrm{MeIm}^{+} \mathrm{Cl}^{-}\right)$, the poly(ECH-MeIm $\left.{ }^{+} \mathrm{TFSI}^{-}\right)$and the equimolar mixture. The solubility was different based on the starting materials: the mixed compound was completely insoluble in acetone or water and soluble in alcohols such as $\mathrm{MeOH}$. The water uptake of the mixture was moderate compared with those of the poly(ECH-MeIm $\left.{ }^{+} \mathrm{Cl}^{-}\right)$and the poly

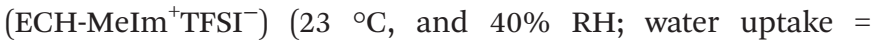
$6.9 \mathrm{wt} \%$, and at $60 \% \mathrm{RH}$; water uptake $=11.6 \mathrm{wt} \%)$. From these results, it is proven that a random copolymer, $\operatorname{poly}(N$-glycidyl- $N$ '-methylimidazolium bis(trifluoromethanesulfonyl)imide-ran- $N$-glycidyl- $N$ '-methylimidazolium chloride), poly $\left(\mathrm{ECH}-\mathrm{MeIm}^{+} \mathrm{Cl}^{-}\right.$-ran-ECH-MeIm $\left.{ }^{+} \mathrm{TFSI}^{-}\right)$, was formed just by mixing the poly $\left(\mathrm{ECH}-\mathrm{MeIm}^{+} \mathrm{Cl}^{-}\right)$and the poly

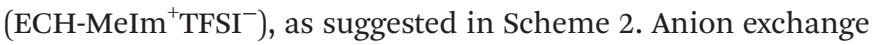
between cationic polyethers would proceed very fast even though the counter cation is a polymeric material. To summarize, the present cationic polyethers are miscible in each other,

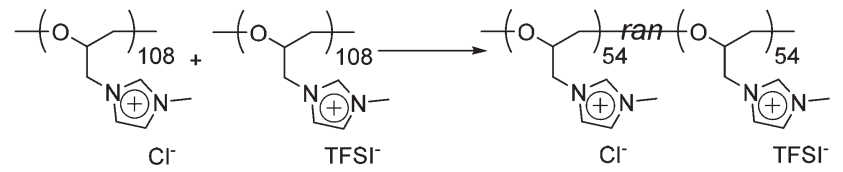

Scheme 2 Synthesis of poly(ECH-Melm ${ }^{+} \mathrm{Cl}^{-}$-ran-ECH-Melm $\left.{ }^{+} \mathrm{TFSI}^{-}\right)$ just by mixing poly $\left(\mathrm{ECH}-\mathrm{Melm}^{+} \mathrm{Cl}^{-}\right)$and poly $\left(\mathrm{ECH}-\mathrm{Melm}^{+} \mathrm{TFSI}^{-}\right)$.

and form a corresponding random copolymer by anion exchange.

Next, the miscibility of the cationic polyethers in ionic liquids was investigated. In the previous section, the water incorporated in poly $\left(\mathrm{ECH}-\mathrm{MeIm}^{+} \mathrm{Cl}^{-}\right)$was verified to be nonfreezing. That is, the hydrated poly $\left(\mathrm{ECH}-\mathrm{MeIm}^{+} \mathrm{Cl}^{-}\right)$possessed neither a glass transition nor a phase transition between $-60{ }^{\circ} \mathrm{C}$ and $80{ }^{\circ} \mathrm{C}$. Taking this significant result into account, we investigated the interaction between the apolar cationic polyether, poly $\left(\mathrm{ECH}-\mathrm{MeIm}^{+} \mathrm{TFSI}^{-}\right)\left(M_{\mathrm{n}(\mathrm{calc})}=45400\right.$, and DP $=$ 108), and a typical ionic liquid, $\left[\mathrm{EMIm}^{+}\right]\left[\mathrm{TFSI}^{-}\right]$, first. The results are summarized in Fig. $8 .\left[\mathrm{EMIm}^{+}\right]\left[\mathrm{TFSI}^{-}\right]$and the poly $\left(\mathrm{ECH}-\mathrm{MeIm}^{+} \mathrm{TFSI}^{-}\right)$are entirely miscible in each other at room temperature. It is interesting that $1: 1$ and $4: 1 \mathrm{wt} / \mathrm{wt}$ mixtures of $\left[\mathrm{EMIm}^{+}\right]\left[\mathrm{TFSI}^{-}\right]$and the poly(ECH-MeIm $\left.{ }^{+} \mathrm{TFSI}^{-}\right)$have neither a melting point nor a glass transition point. $\left[\mathrm{EMIm}^{+}\right]\left[\mathrm{TFSI}^{-}\right]$is a molten salt with an experimentally observed melting point at around $-15{ }^{\circ} \mathrm{C}$ (Fig. 8(b)). When $20 \mathrm{wt} \%$ of the poly $\left(\mathrm{ECH}-\mathrm{MeIm}^{+} \mathrm{TFSI}^{-}\right)$was added to $80 \mathrm{wt} \%$ of $\left[\mathrm{EMIm}^{+}\right]\left[\mathrm{TFSI}^{-}\right]$, both the melting point of $\left[\mathrm{EMIm}^{+}\right]\left[\mathrm{TFSI}^{-}\right]$ and the glass transition point of the poly $\left(\mathrm{ECH}-\mathrm{MeIm}^{+} \mathrm{TFSI}^{-}\right)$ entirely disappeared between $-70{ }^{\circ} \mathrm{C}$ and $100{ }^{\circ} \mathrm{C}$ (Fig. 8(c)). The mixture of equivalent weights of $\left[\mathrm{EMIm}^{+}\right]\left[\mathrm{TFSI}^{-}\right]$and the poly (ECH-MeIm $\left.{ }^{+} \mathrm{TFSI}^{-}\right)$also displayed neither a melting point nor a glass transition (Fig. 8(d)) in the cooling and heating steps. To summarize this result, the poly(ECH-MeIm $\left.{ }^{+} \mathrm{TFSI}^{-}\right)$was miscible in $\left[\mathrm{EMIm}^{+}\right]\left[\mathrm{TFSI}^{-}\right]$even at low temperature, and it played a role as a freezing point depressant for $\left[\mathrm{EMIm}^{+}\right]\left[\mathrm{TFSI}^{-}\right]$.

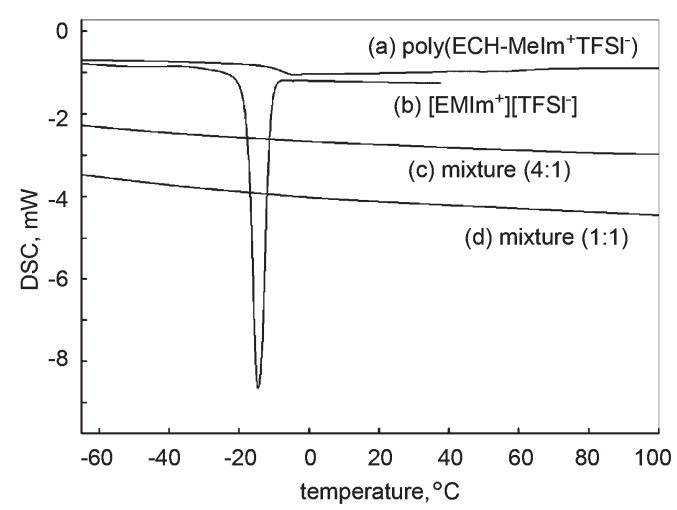

Fig. 8 DSC thermograms (heating steps) of (a) poly(ECH-Melm ${ }^{+} \mathrm{TFSI}^{-}$) $\left(M_{\text {n(calc })}=45400\right.$, and DP $\left.=108\right),\left(\right.$ b) $\left[\mathrm{EMIm}^{+}\right]\left[\mathrm{TFSI}^{-}\right]$, (c) a mixture of $80 \mathrm{wt} \%\left[\mathrm{EMIm}^{+}\right]\left[\mathrm{TFSI}^{-}\right]$and $20 \mathrm{wt} \%$ of the poly $\left(\mathrm{ECH}-\mathrm{Melm}^{+} \mathrm{TFSI}^{-}\right)$, and (d) a mixture of $50 \mathrm{wt} \%$ [EMIm $\left.{ }^{+}\right]\left[\mathrm{TFSI}^{-}\right]$and $50 \mathrm{wt} \%$ of the poly $\left(\mathrm{ECH}-\mathrm{Melm}^{+} \mathrm{TFSI}^{-}\right.$) (determined under $\mathrm{N}_{2}$, at $5{ }^{\circ} \mathrm{C} \mathrm{min}^{-1}$ for each step). 
Table 4 Miscibility of the cationic polyethers ${ }^{a}$ in ionic liquids

\begin{tabular}{|c|c|c|c|}
\hline Run & Ionic compounds/weight ratio & & Thermal behavior $^{b}$ \\
\hline 1 & 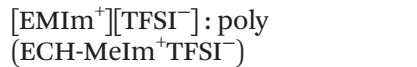 & $1: 1$ & Non-freezing \\
\hline 2 & 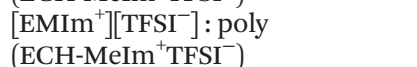 & $4: 1$ & Non-freezing \\
\hline 3 & $\begin{array}{l}{\left[\mathrm{BMIm}^{+}\right]\left[\mathrm{TFSI}^{-}\right]: \text {poly }} \\
\left(\mathrm{ECH}_{\left.-\mathrm{MeIm}^{+} \mathrm{TFSI}^{-}\right)}\right.\end{array}$ & $4: 1$ & Non-freezing \\
\hline 4 & {$\left[\mathrm{EMIm}^{+}\right]\left[\mathrm{TFSI}^{-}\right]:\left[\mathrm{BMIm}^{+}\right]\left[\mathrm{TFSI}^{-}\right]$} & $1: 1$ & Non-freezing \\
\hline 5 & {$\left[\mathrm{EMIm}^{+}\right]\left[\mathrm{TFSI}^{-}\right]:\left[\mathrm{BMIm}^{+}\right]\left[\mathrm{TFSI}^{-}\right]$} & $4: 1$ & $\begin{array}{l}T_{\mathrm{cc}}=-35^{\circ} \mathrm{C}^{c}, T_{\mathrm{m}}= \\
-23^{\circ} \mathrm{C}^{d}\end{array}$ \\
\hline 6 & $\begin{array}{l}{\left[\mathrm{BMIm}^{+}\right]\left[\mathrm{Cl}^{-}\right] \text {: poly }} \\
\left(\mathrm{ECH}-\mathrm{MeIm}^{+} \mathrm{Cl}^{-}\right)\end{array}$ & $4: 1$ & $T_{\mathrm{g}}=-48^{\circ} \mathrm{C}$ \\
\hline 7 & {$\left[\mathrm{BMIm}^{+}\right]\left[\mathrm{Cl}^{-}\right]:\left[\mathrm{EMIm}^{+}\right]\left[\mathrm{Cl}^{-}\right]$} & $4: 1$ & $\begin{array}{l}T_{\mathrm{g}}=-44^{\circ} \mathrm{C}, T_{\mathrm{cc}}= \\
35^{\circ} \mathrm{C}, T_{\mathrm{m}}=59^{\circ} \mathrm{C}\end{array}$ \\
\hline 8 & $\begin{array}{l}{\left[\mathrm{EMIm}^{+}\right]\left[\mathrm{BF}_{4}^{-}\right]: \text {poly }} \\
\left(\mathrm{ECH}-\mathrm{MeIm}^{+} \mathrm{BF}_{4}^{-}\right)\end{array}$ & $4: 1$ & Non-freezing \\
\hline 9 & {$\left[\mathrm{EMIm}^{+}\right]\left[\mathrm{BF}_{4}^{-}\right]:\left[\mathrm{BMIm}^{+}\right]\left[\mathrm{BF}_{4}^{-}\right]$} & $4: 1$ & Non-freezing \\
\hline 10 & $\begin{array}{l}{\left[\mathrm{EMIm}^{+}\right]\left[\mathrm{TFSI}^{-}\right] \text {: poly }} \\
\left(\mathrm{ECH}_{-} \mathrm{MeIm}^{+} \mathrm{Cl}^{-}\right)\end{array}$ & $4: 1$ & Non-freezing \\
\hline 11 & {$\left[\mathrm{EMIm}^{+}\right]\left[\mathrm{TFSI}^{-}\right]:\left[\mathrm{EMIm}^{+}\right]\left[\mathrm{Cl}^{-}\right]$} & $4: 1$ & Non-freezing \\
\hline 12 & $\begin{array}{l}{\left[\mathrm{EMIm}^{+}\right]\left[\mathrm{TFSI}^{-}\right]: \text {poly }} \\
\left(\mathrm{ECH}_{-} \mathrm{MeIm}^{+} \mathrm{BF}_{4}{ }^{-}\right)\end{array}$ & $4: 1$ & Non-freezing \\
\hline 13 & {$\left[\mathrm{EMIm}^{+}\right]\left[\mathrm{TFSI}^{-}\right]:\left[\mathrm{EMIm}^{+}\right]\left[\mathrm{BF}_{4}^{-}\right]$} & $4: 1$ & Non-freezing \\
\hline
\end{tabular}

${ }^{a}$ Poly $\left(\mathrm{ECH}-\mathrm{MeIm}^{+} \mathrm{Cl}^{-}\right) \quad\left(M_{\mathrm{n}(\mathrm{calc})}=18900 ; \mathrm{DP}=108\right)$, poly

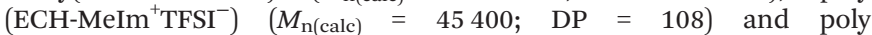
$\left(\mathrm{ECH}-\mathrm{MeIm}^{+} \mathrm{BF}_{4}^{-}\right)\left(M_{\mathrm{n}(\mathrm{calc})}=24500 ; \mathrm{DP}=108\right)$ as described in Fig. $2-4$ were employed. ${ }^{b}$ Determined under $\mathrm{N}_{2}$, at $5{ }^{\circ} \mathrm{C} \mathrm{min}^{-1}$ between $-80^{\circ} \mathrm{C}$ and $150{ }^{\circ} \mathrm{C} .{ }^{c} T_{\mathrm{cc}}$ : Cold crystallization temperature. ${ }^{d} T_{\mathrm{m}}$ : Melting point.

Furthermore, three cationic polyethers were mixed in imidazolium-based ionic liquids. Table 4 summarizes the miscibility and the thermal properties of the mixtures of ionic liquids and cationic polyethers. Poly $\left(\mathrm{ECH}-\mathrm{MeIm}{ }^{+} \mathrm{TFSI}^{-}\right)$was miscible in $\left[\mathrm{EMIm}^{+}\right]\left[\mathrm{TFSI}^{-}\right]$and in $\left[\mathrm{BMIm}^{+}\right]\left[\mathrm{TFSI}^{-}\right]$. From our results a $4: 1$ wt/wt mixture of $\left[\mathrm{EMIm}^{+}\right]\left[\mathrm{TFSI}^{-}\right]$and $\left[\mathrm{BMIm}^{+}\right]\left[\mathrm{TFSI}^{-}\right]$froze at $-23{ }^{\circ} \mathrm{C}$. As stated above, a $4: 1 \mathrm{wt} / \mathrm{wt}$

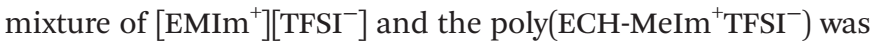
non-freezing. One of the significant characteristics of the poly $\left(\mathrm{ECH}-\mathrm{MeIm}^{+} \mathrm{Cl}^{-}\right)$is the freezing point depression of $\left[\mathrm{BMIm}^{+}\right]\left[\mathrm{Cl}^{-}\right]$. A mixture of $\left[\mathrm{BMIm}^{+}\right]\left[\mathrm{Cl}^{-}\right]$and the poly $\left(\mathrm{ECH}-\mathrm{MeIm}^{+} \mathrm{Cl}^{-}\right)(4: 1 \mathrm{wt} / \mathrm{wt})$ had a low glass transition point at $-48{ }^{\circ} \mathrm{C}$ and no phase transition. In contrast, a $4: 1 \mathrm{wt} / \mathrm{wt}$ mixture of $\left[\mathrm{BMIm}^{+}\right]\left[\mathrm{Cl}^{-}\right]$and $\left[\mathrm{EMIm}^{+}\right]\left[\mathrm{TFSI}^{-}\right]$showed cold-crystallization at $35^{\circ} \mathrm{C}$ and melted at $59{ }^{\circ} \mathrm{C}$, suggesting phase separation at low temperature. Similarly, $4: 1 \mathrm{wt} / \mathrm{wt}$ mixtures of $\left[\mathrm{EMIm}^{+}\right]\left[\mathrm{BF}_{4}{ }^{-}\right]$with the poly $\left(\mathrm{ECH}-\mathrm{MeIm}^{+} \mathrm{BF}_{4}{ }^{-}\right),\left[\mathrm{EMIm}^{+}\right]\left[\mathrm{TFSI}^{-}\right]$ with the poly $\left(\mathrm{ECH}-\mathrm{MeIm}^{+} \mathrm{Cl}^{-}\right)$, and $\left[\mathrm{EMIm}^{+}\right]\left[\mathrm{TFSI}^{-}\right]$with the poly $\left(\mathrm{ECH}-\mathrm{MeIm}^{+} \mathrm{BF}_{4}{ }^{-}\right)$were found to be non-freezing. It has been already reported that $\left[\mathrm{EMIm}^{+}\right]\left[\mathrm{TFSI}^{-}\right],\left[\mathrm{EMIm}^{+}\right]\left[\mathrm{Cl}^{-}\right]$and $\left[\mathrm{EMIm}^{+}\right]\left[\mathrm{BF}_{4}^{-}\right]$are highly miscible in each other even at low temperature. $^{49-52}$

To conclude this section, the miscibility of the cationic polyethers in ionic liquids was identical to or higher than those of ionic liquids. Since the melting points of the ionic liquids are not very low, the fluidity and the ionic conductivity of the ionic liquids sometimes decrease at low temperature. Similarly, the ionic conductivities of polymer electrolytes are always modest at low temperature. In terms of ionic liquids, the melting points disappeared by adding cationic polyethers. In the meantime, the glass transition points of the cationic polyethers disappeared with the addition of ionic liquids. Therefore, the present composite of ionic liquid and cationic polyether can be regarded as a new class of ionic material which can eliminate the drawbacks of conventional ionic liquids and ionomers. Now, further study is in progress to uncover the fundamental properties of the present ionic liquid composites and elucidate the basic requirements for this unique phenomenon.

\section{Conclusions}

Cationic polyethers were successfully synthesized and their properties and functions were characterized. Cationic polyethers were prepared by the living ring-opening anionic polymerization of epichlorohydrin followed by quantitative quaternization of the chloromethyl group by 1-methylimidazole and by anion exchange. Consequently, the cationic polyethers had both an ionic liquid group and a polyether chain in each repeating unit. Various functions are dependent on the choice of the ionic moiety. In fact, poly(ECH-MeIm $\left.{ }^{+} \mathrm{Cl}^{-}\right)$was characterized to be highly deliquescent in nature and have an excellent ionic conductivity when hydrated. The water confined in poly $\left(\mathrm{ECH}_{-} \mathrm{MeIm}^{+} \mathrm{Cl}^{-}\right)$was non-freezing water. The cationic polyethers generally displayed high thermal stability. The miscibility of the cationic polyethers in themselves and in ionic liquids was higher than that of ionic liquids. The cationic polyethers played a role as freezing point depressants for ionic liquids. It can be emphasized that the present cationic polyethers are very unique compounds, having extraordinary functions that come from the combination of ionic liquid moieties and the main chain of polyoxyethylene. We have already investigated another type of cationic polyether with various onium groups and various counter anions. Moreover, a cross-linkable cationic polyether was also developed by the cationization of a copolymer of ECH and unsaturated epoxide. The functions and properties of further cationic polyethers will be detailed in a following report.

\section{Conflicts of interest}

There are no conflicts to declare.

\section{Acknowledgements}

We would like to express appreciation to the Tosoh Corporation for the GPC analyses of the poly(ECH-MeIm $\left.{ }^{+} \mathrm{Cl}^{-}\right)$samples. $\mathrm{SH}$ thanks Mr Yuta Makita for the helpful discussion. We are grateful to Dr Renata Drozdzak for the scientific support.

\section{Notes and references}

\author{
1 J. S. Wilkes, Green Chem., 2002, 4, 73.
}


2 N. V. Plechkova and K. R. Seddon, Chem. Soc. Rev., 2008, $37,123$.

3 T. Welton, Chem. Rev., 1999, 99(8), 2071.

4 J. S. Wilkes and M. J. Zawarotko, J. Chem. Soc., Chem. Commun., 1992, 965.

5 J. Yuan and M. Antonietti, Polymer, 2011, 52, 1469.

6 D. Mecerreyes, Prog. Polym. Sci., 2011, 36, 1629.

7 J. Yuan, D. Mecerreyes and M. Antonietti, Prog. Polym. Sci., 2013, 38, 1009.

8 J. C. Salamone, S. C. Israel, P. Tailor and B. Snider, Polymer, 1973, 14, 639.

9 R. L. Weber, Y. Ye, S. M. Banik, Y. A. Elabd, M. A. Hickner and M. K. Mahantthappa, J. Polym. Sci., Part B: Polym. Phys., 2011, 49, 1287.

10 K. M. Meek and Y. A. Elabd, Macromolecules, 2015, 48, 7071.

11 K. M. Meek, S. Sharick, Y. Ye, K. I. Winey and Y. A. Elabd, Macromolecules, 2015, 48, 4850.

12 Y. Ye, S. Sharick, E. M. Davis, K. I. Winey and Y. A. Elabd, ACS Macro Lett., 2013, 2, 575.

13 U. H. Choi, Y. Ye, D. S. Cruz, W. Liu, K. I. Winey, Y. A. Elabd, J. Runt and R. H. Colby, Macromolecules, 2014, 47, 777.

14 J.-H. H. Wang, C. H.-C. Yang, H. Masser, H.-S. Shiau, M. V. O'Reilly, K. I. Winey, J. Runt, P. C. Painter and R. H. Colby, Macromolecules, 2015, 48, 7273.

15 C. M. Evans, C. R. Bridges, G. E. Sanoja, J. Bartels and R. A. Segalman, ACS Macro Lett., 2016, 5, 925.

16 C. M. Evans, G. E. Sanoja, B. C. Popere and R. A. Segalman, Macromolecules, 2016, 49, 395.

17 K. Ueno, J. Murai, K. Ikeda, S. Tsuzuki, M. Tsuchiya, R. Tatara, T. Mandai, Y. Umebayashi, K. Dokko and M. Watanabe, J. Phys. Chem. C, 2016, 120, 15792.

18 H. Asai, K. Fujii, T. Ueki, T. Sakai, U. Chung, M. Watanabe, Y.-S. Han, T.-H. Kim and M. Shibayama, Macromolecules, 2012, 45, 3902.

19 H. Yoshimitsu, A. Kanazawa, S. Kanaoka and S. Aoshima, Macromolecules, 2012, 45, 9427.

20 T. K. Carlisle, E. F. Wiesenauer, G. D. Nicodemus, D. L. Gin and R. D. Noble, Ind. Eng. Chem. Res., 2013, 52, 1023.

21 Y. Kohno, S. Saita, Y. Men, J. Yuan and H. Ohno, Polym. Chem., 2015, 6, 2163.

22 For a book: N. Hadjichristidis and A. Hirao, Anionic Polymerization: Principles, Practice, Strength, Consequences and Application, Springer, Japan, 2015.

23 E. J. Vandenberg, J. Polym. Sci., 1960, 47, 486.

24 J. Furukawa, T. Tsuruta, R. Sakata, T. Saegusa and A. Kawasaki, Makromol.Chem., 1959, 32, 90.

25 S. Kambara and A. Takahashi, Makromol. Chem., 1963, 63, 89.

26 T. Aida, Y. Maekawa, S. Asano and S. Inoue, Macromolecules, 1988, 21, 1195.

27 N. Emig, H. Nguyen, H. Krautschield, R. Reau, J.-B. Cazaux and G. Bertrand, Organometallics, 1998, 17, 3599.

28 W. Braune and J. Okuda, Angew. Chem., Int. Ed., 2003, 42, 64.
29 C. Billouard, S. Carlotti, P. Desbois and A. Deffieux, Macromolecules, 2004, 37, 4038.

30 S. Carlotti, A. Labbé, V. Rejsek, S. Doutaz, M. Gervais and A. Deffieux, Macromolecules, 2008, 41, 7058.

31 S. Hayano and Y. Tsunogae, Japanese Patent 5229464, 2008.

32 D. Stoica, L. Ogier, L. Akrour, F. Alloin and J.-F. Fauvarque, Electrochim. Acta, 2007, 53, 1596.

33 D. Stoica, F. Alloin, S. Marais, D. Langevin, C. Chappy and P. Judeinstein, J. Phys. Chem. B, 2008, 112, 12338.

34 Before starting this study, we tried to quaternize commercially available poly(ECH), of which the MW was higher than 1000000 . The quaternization reaction was very sluggish: for example, only $20 \%$ of the chloromethyl was cationized by 2 equivalents of 1 -imidazole after 10 days reaction at $100{ }^{\circ} \mathrm{C}$.

35 H. Hu, W. Yuan, Z. Jia and G. L. Baker, RSC Adv., 2015, 5, 3135.

36 H. Hu, W. Yuan, L. Lu, H. Zhao, Z. Jia and G. L. Baker, J. Polym. Sci., Part A: Polym. Chem., 2014, 52, 2104.

37 S. Hayano, H. Yonemaru and K. Ohta, WO2012/133786.

38 S. Hayano, K. Ohta and T. B. Hoang, Chem. Lett., 2017, 46, 1033.

39 G. D. Smith, O. Borodin, L. Li, H. Kim, Q. Lin, J. E. Bara, D. L. Gin and R. Noble, Phys. Chem. Chem. Phys., 2008, 10, 6301.

40 It should be noted that the present poly(ECH) samples have chloromethyl groups at the repeating units and one bromomethyl group at the initiation end which came from $n$ - $\mathrm{Bu}_{4} \mathrm{NBr}$ as the initiator. The bromomethyl group was also cationized by 1-methylimidazole during the quaternization. Therefore each cationized polymer has one imidazolium group at the initiation end. We have omitted the end groups in Scheme 1 for the clarity of the focus in this study.

41 All of the polymer samples were dried in vacuo for $48 \mathrm{~h}$ at first, and after that they were put in a sample pan and covered up under $\mathrm{N}_{2}$ in a glove-box. The lid of the sample pan was removed quickly just before loading in the TG/DTA apparatus. Unfortunately our TG/DTA was situated not in a dry room but in a regular laboratory. Therefore all of the samples were exposed to air slightly just before loading in to the equipment. As a result the deliquescent poly $\left(\mathrm{ECH}-\mathrm{MeIm}^{+} \mathrm{Cl}^{-}\right)$was hydrated slightly and, in turn, the TG/DTA measurement detected the evaporation of water. Thus, in the case of the poly $\left(\mathrm{ECH}-\mathrm{MeIm}^{+} \mathrm{Cl}^{-}\right)$, the $T_{\mathrm{d} 5 \%}$ was estimated excluding the weight-loss from the evaporation of the confined water.

42 K. Tanaka, F. Ishiguro and Y. Chujo, J. Am. Chem. Soc., 2010, 132, 17649.

43 K. Tanaka and Y. Chujo, Polym. J., 2013, 45, 247.

44 L. Tian, X. Shu and J. Zhu, Adv. Mater., 2007, 19, 4548.

45 H. M. L. Thijs, C. R. Becer, C. Guerrero-Sanchez, D. Fournier, R. Hoogenboom and U. S. Schubert, J. Mater. Chem., 2007, 17, 4864. 
46 For instance, ionic liquids such as $\left[\mathrm{EMIm}^{+}\right]\left[\mathrm{Cl}^{-}\right]$exhibit high capacities for moisture absorption, and poly(ethylene oxide) is well known as an absorbent and hydrophilic polymer.

47 The aluminum sample pan for the DSC measurement was covered up tightly with the aluminum pan lid, in order to not observe an endothermic peak from the evaporation of the incorporated water. As a result, the incorporated water didn't evaporate easily at around $60^{\circ} \mathrm{C}$. A slight endotherm was observable in the DSC thermogram of the hydrated poly $\left(\mathrm{ECH}-\mathrm{MeIm}^{+} \mathrm{Cl}^{-}\right)$above $80^{\circ} \mathrm{C}$, probably due to the slow evaporation of the water inside of the sealed DSC pan. In contrast, the TG/DTA of the lightly hydrated poly $\left(\mathrm{ECH}-\mathrm{MeIm}^{+} \mathrm{Cl}^{-}\right)$was measured after removing the lid of the sample pan, therefore the water easily evaporated to observe the weight loss above $60^{\circ} \mathrm{C}$.

48 T. Okada, G. Xie, O. Gorseth, S. Kjelstrup, N. Nakamura and T. Arimura, Electrochim. Acta, 1998, 43, 3741.

49 R. P. Matthews, I. J. Viller-Garcia, C. C. Weber, J. Griffith, F. Cameron, P. A. Hunt and T. Welton, Phys. Chem. Chem. Phys., 2016, 18, 8608.

50 S. Omer, J. Lemus, E. Ruiz, V. R. Ferro, J. Ortega and J. Palomar, J. Phys. Chem. B, 2014, 118, 2442.

51 G. Annat, M. Forsyth and D. R. MacFarlane, J. Phys. Chem. $B, 2012,116,8251$.

52 H. Niedermeyer, J. P. Hallett, I. J. Viller-Garcia, P. A. Hunt and T. Welton, Chem. Soc. Rev., 2012, 41, 7780. 